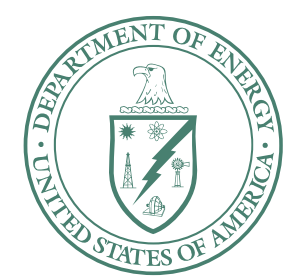

U.S. Department of Energy

Idaho Operations Office

\title{
Action Memorandum for Decommissioning the Engineering Test Reactor Complex under the Idaho Cleanup Project
}

January 2007 
DOE/ID-11303

Revision 0

Project No. 23415

\section{Action Memorandum for Decommissioning the Engineering Test Reactor Complex under the Idaho Cleanup Project}

January 2007

Prepared for the 
Signature sheet for the Action Memorandum covering the ETR Complex decommissioning activities at the U.S. Department of Energy's Idaho National Laboratory. This action is conducted by the U.S. Department of Energy with the concurrence of the U.S. Environmental Protection Agency and the Idaho Department of Environmental Quality.
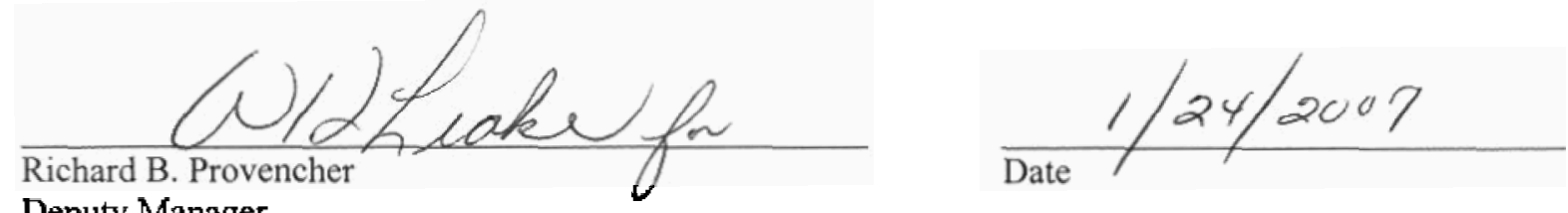

Deputy Manager

U.S. Department of Energy Idaho Operations Office 

Signature sheet for the Action Memorandum covering the ETR Complex decommissioning activities at the U.S. Department of Energy's Idaho National Laboratory. This action is conducted by the U.S. Department of Energy with the concurrence of the U.S. Environmental Protection Agenoy and the Idaho Department of Environmental Qualiry.

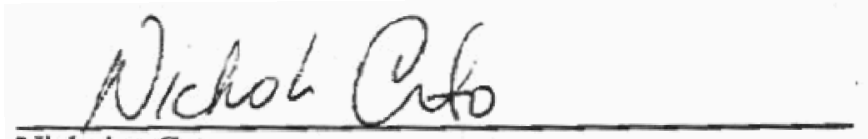

Nicholas Ceto

Idaho National Laboratory Program Manager

Region 10

U.S. Environmental Protection Agency

$\frac{24 \text { Jan } 07}{\text { Date }}$



Signature sheer for the Action Memorandum covering the ETR Complex decommissioning activities at the U.S. Department of Energy's Idaho National Laboratory. This action is conducted by the U.S.

Department of Energy with the concurrence of the U.S. Environmental Protection Agency and the Idaho Deparment of Environmental Quality.

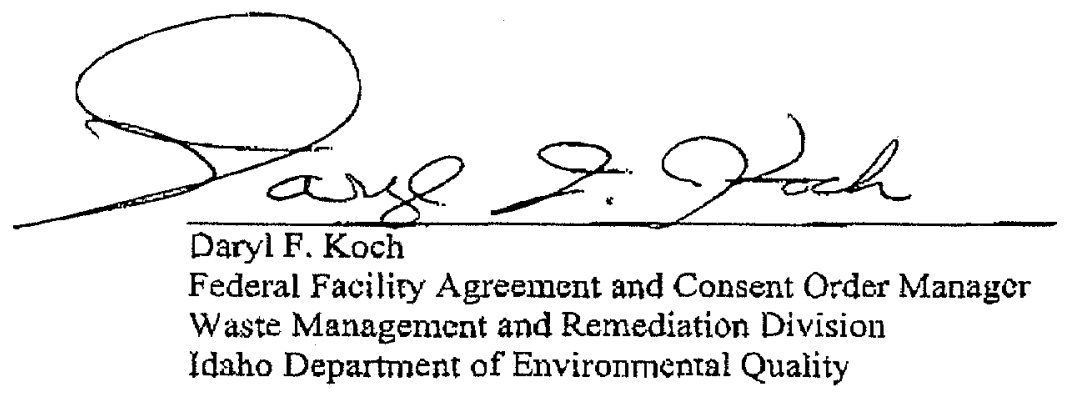

- Saruary $25,200 \%$ Idaho Department of Environmental Quality 



\begin{abstract}
This Action Memorandum documents the selected alternative for decommissioning of the Engineering Test Reactor at the Idaho National Laboratory under the Idaho Cleanup Project. Since the missions of the Engineering Test Reactor Complex have been completed, an engineering evaluation/cost analysis that evaluated alternatives to accomplish the decommissioning of the Engineering Test Reactor Complex was prepared and released for public comment. The scope of this Action Memorandum is to encompass the final end state of the Complex and disposal of the Engineering Test Reactor vessel. The selected removal action includes removing and disposing of the vessel at the Idaho CERCLA Disposal Facility and demolishing the reactor building to ground surface.
\end{abstract}




\section{EXECUTIVE SUMMARY}

This Action Memorandum documents the selected alternative for decommissioning of the Engineering Test Reactor (ETR) at the Idaho National Laboratory (INL) under the Idaho Cleanup Project. Preparation of this Action Memorandum has been performed in accordance with the Comprehensive Environmental Response, Compensation, and Liability Act (CERCLA) (42 USC § 9601 et seq.), as amended by the "Superfund Amendments and Reauthorization Act of 1986" (Public Law 99-499), and in accordance with the "National Oil and Hazardous Substances Pollution Contingency Plan" (40 CFR 300). This action is consistent with the joint U.S. Department of Energy (DOE) and Environmental Protection Agency (EPA) Policy on Decommissioning of Department of Energy Facilities Under the Comprehensive Environmental Response, Compensation, and Liability Act (DOE and EPA 1995), which establishes the CERCLA non-time-critical removal action process as an approach for decommissioning. This approach satisfies environmental review requirements and provides for stakeholder involvement, while providing a framework for selecting the decommissioning alternative. An Administrative Record has been established to record information used to support the selected alternative as well as provide documentation of decisions and the progress of the removal action.

An engineering evaluation/cost analysis (EE/CA) that evaluated alternatives to accomplish the decommissioning of the ETR buildings and structures at the ETR Complex was prepared and released for public comment. Comments received during the public comment period were considered for inclusion into the Action Memorandum and are included in Appendix A.

The scope of the EE/CA is the final end state of the ETR Complex and disposal site for the ETR vessel. Four alternatives were evaluated in the EE/CA and Alternative 3, "Removal and Disposal of the ETR Vessel at an On-Site Disposal Facility," with disposal at the Idaho CERCLA Disposal Facility (ICDF) was the recommended and, ultimately, the selected alternative subsequent to Agency and public reviews. This alternative meets the remedial action objectives (RAOs) regarding long-term risk, minimizes short-term worker risk and radiation exposure, reduces the footprint of waste sites at the INL, is cost effective, and provides a safe and stable configuration that is environmentally sound.

The ETR vessel meets the ICDF waste acceptance criteria and would be transported and disposed of as low-level radioactive waste at the ICDF. Any remaining voids in the vessel would be filled with grout at the disposal site. The aboveground portions of the reactor building would be demolished to below ground surface and the resultant demolition material may be used as backfill or disposed of in accordance with the applicable disposal site waste acceptance criteria. Materials left in place include inert, nonputrescible material located below the ground surface, such as piping, equipment, electrical conduit, utility systems, structural steel, and other residual clean or contaminated materials with low-level radioactive and/or chemically hazardous substances that do not present an unacceptable risk in accordance with the RAOs for Final Record of Decision Test Reactor Area Operable Unit 2-13, Idaho National Engineering and Environmental Laboratory, Idaho Falls, Idaho, (DOE-ID 1997) and Explanation of Significant Differences to the Record of Decision for Test Reactor Area Operable Unit 2-13 (DOE-ID 2000). Excavations and remaining belowgrade structures would be grouted as necessary and backfilled to grade. Clean soil would cover the locations of ETR Complex buildings and structures.

The selected alternative meets the RAOs regarding long-term risk, minimizes short-term worker risk and radiation exposure, and is cost effective, and provides a safe and stable configuration that is environmentally sound. The end state provided by Alternative 3 is consistent with the DOE goal to minimize long term surveillance and maintenance costs by reducing the footprints and consolidating waste from contaminated facilities. 


\section{CONTENTS}

ABSTRACT iii

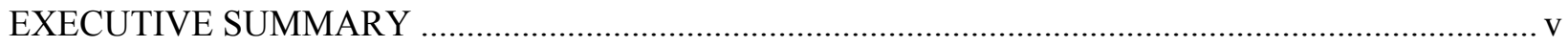

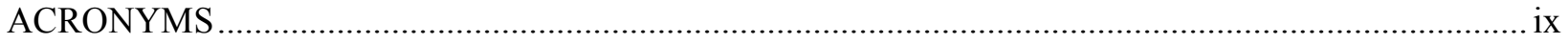

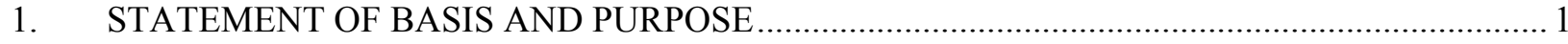

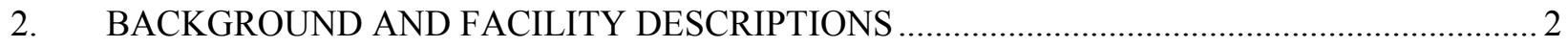

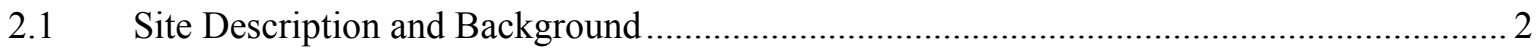

2.1.1 Idaho National Laboratory Site and Idaho Cleanup Project............................. 2

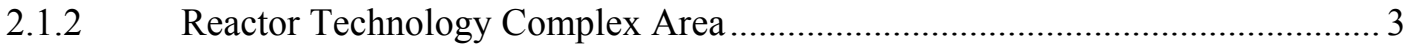

2.1.3 Engineering Test Reactor Complex ................................................................... 4

2.2 Previous Closure/Cleanup Activities at the ETR Complex ........................................... 8

2.2.1 Comprehensive Environmental Response, Compensation, and

Liability Act Activities at the Reactor Technology Complex …......................... 8

2.2.2 Voluntary Consent Order Activities............................................................... 8

2.2.3 Other Activities at the ETR Complex …......................................................... 8

3. THREAT TO PUBLIC HEALTH, WELFARE, AND/OR THE ENVIRONMENT ....................... 9

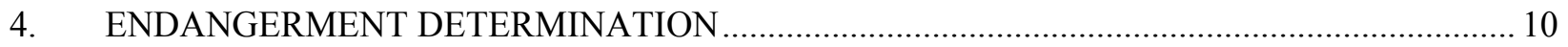

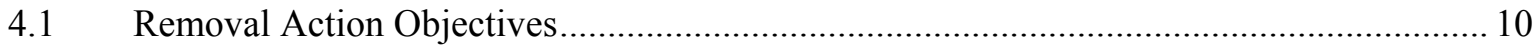

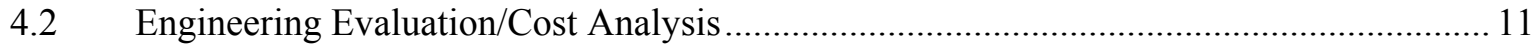

4.2.1 Alternative 1-No Action, Continued Surveillance and Maintenance .............. 11

4.2.2 Alternative 2-Grouting ETR Vessel in Place............................................... 11

4.2.3 Alternative 3-Removal and Disposal of ETR Vessel at an On-Site Disposal Facility ............................................................................................ 11

4.2.4 Alternative 4-Removal and Disposal of ETR Vessel at an Off-Site Disposal Facility ....................................................................................... 12

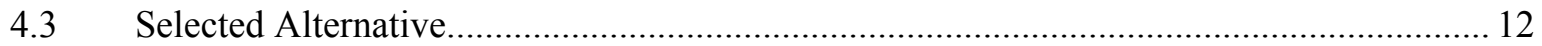

4.4 Compliance with Environmental Regulations, Including Those That Are Applicable or Relevant and Appropriate Requirements

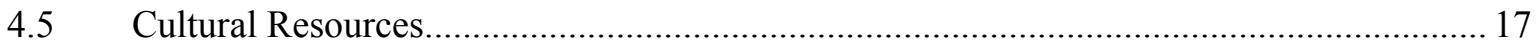

4.6 Compliance with Disposal Facility Waste Acceptance Criteria ........................................ 18

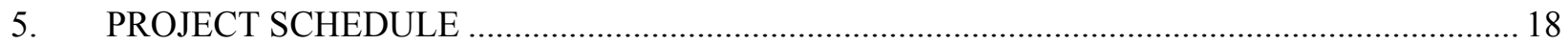




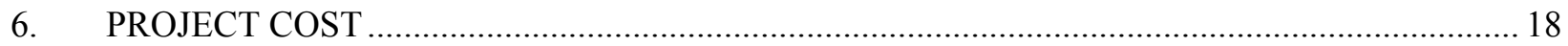

7. EXPECTED CHANGE SHOULD ACTION BE DELAYED OR NOT TAKEN......................... 18

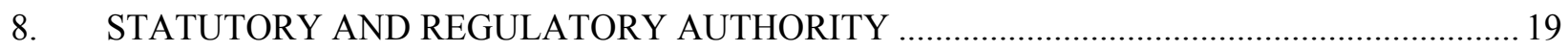

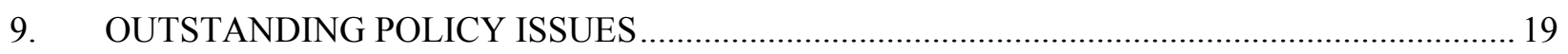

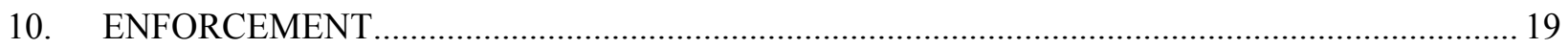

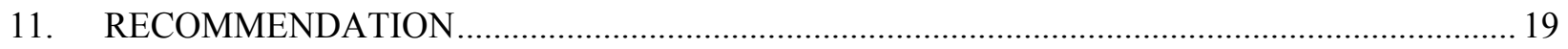

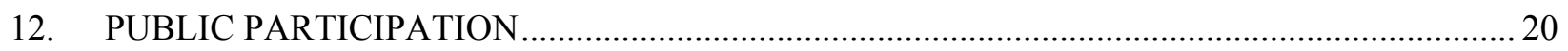

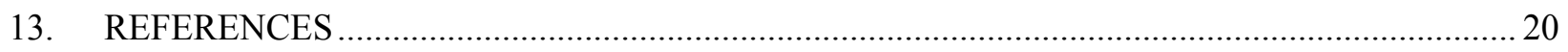

Appendix A-Public Comments Received during the Comment Period and Responses to

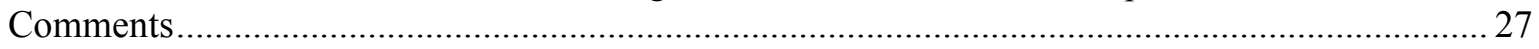

Appendix B —Public and Tribe Comment Resolution Matrix ............................................................. 37

Appendix C—Citizen's Advisory Board ETR Engineering Evaluation/Cost Analysis

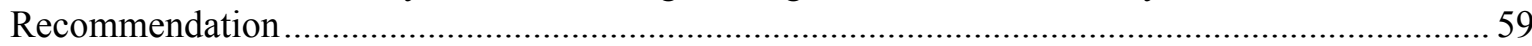

\section{FIGURES}

1. Map of the Idaho National Laboratory Site showing the location of the Reactor Technology Complex and other major facilities

2. Map of the Reactor Technology Complex with the Engineering Test Reactor Complex highlighted 5

3. Engineering Test Reactor vessel installation in 1956 6

\section{TABLES}

1. Summary of applicable or relevant and appropriate requirements for the Engineering Test Reactor Complex non-time-critical removal action 


\section{ACRONYMS}

ARAR applicable or relevant and appropriate requirement

CERCLA Comprehensive Environmental Response, Compensation, and Liability Act

CFR Code of Federal Regulations

COC contaminant of concern

CRMP Cultural Resources Management Plan

DEQ (Idaho) Department of Environmental Quality

DOE Department of Energy

DOE-ID Department of Energy Idaho Operations Office

$\mathrm{EE} / \mathrm{CA} \quad$ engineering evaluation/cost analysis

EPA Environmental Protection Agency

ETR Engineering Test Reactor

GEEL General Electric Experimental Loop

HWMA Hazardous Waste Management Act

ICDF Idaho CERCLA Disposal Facility

IDAPA Idaho Administrative Procedures Act

INL Idaho National Laboratory

LLW low-level waste

NHPA National Historic Preservation Act

NTCRA non-time-critical removal action

OU operable unit

PCB polychlorinated biphenyl

RAO remedial action objective/removal action objective

RCRA Resource Conservation and Recovery Act

ROD Record of Decision

RTC Reactor Technology Complex

RWMC Radioactive Waste Management Complex

S\&M surveillance and maintenance

SRPA Snake River Plain Aquifer

TRA Test Reactor Area 
TSCA Toxic Substances Control Act

USC United States Code

VCO Voluntary Consent Order

WAC Waste Acceptance Criteria 


\section{Action Memorandum for Decommissioning the Engineering Test Reactor Complex under the Idaho Cleanup Project}

\section{STATEMENT OF BASIS AND PURPOSE}

Development of the engineering evaluation/cost analysis (EE/CA) for the decommissioning of the Engineering Test Reactor Complex (DOE-ID 2006a) and this Action Memorandum has been performed in accordance with the Comprehensive Environmental Response, Compensation, and Liability Act (CERCLA) (42 United States Code [USC] § 9601 et seq.), as amended by the "Superfund Amendments and Reauthorization Act of 1986" (Public Law 99-499), and in accordance with the "National Oil and Hazardous Substances Pollution Contingency Plan" (40 Code of Federal Regulations [CFR] 300). Although decommissioning of the Engineering Test Reactor (ETR) Complex was not specifically addressed in the Final Record of Decision Test Reactor Area Operable Unit 2-13, Idaho National Engineering and Environmental Laboratory, Idaho Falls, Idaho (DOE-ID 1997) or the Explanation of Significant Differences to the Record of Decision for Test Reactor Area Operable Unit 2-13 (DOE-ID 2000), this removal action is consistent with the remedial action objectives of the Record of Decision (ROD) and supports the overall remediation goals established through the Federal Facility Agreement and Consent Order for the Idaho National Engineering Laboratory (DOE-ID 1991) process for Waste Area Group 2. Waste Area Group 2 is located at the Reactor Technology Complex (RTC) within the Idaho National Laboratory (INL), formerly known as the Test Reactor Area (TRA) and Idaho National Engineering and Environmental Laboratory (INEEL), respectively. The removal action will place the facility in a final configuration that remains protective of human health and the environment. Preparation of this Action Memorandum is consistent with the joint U.S. Department of Energy (DOE) and U.S. Environmental Protection Agency (EPA) Policy on Decommissioning of Department of Energy Facilities Under the Comprehensive Environmental Response, Compensation, and Liability Act (DOE and EPA 1995), which establishes the CERCLA non-time-critical removal action (NTCRA) process as an approach for decommissioning.

The scope of this Action Memorandum is the final end state of the ETR Complex and final disposal site for the ETR vessel. A continuation of the deactivation activities that were begun in 1981 are proceeding in advance of the NTCRA Action Memorandum and are not included in the scope of the NTCRA. These initial activities involve removal of some piping and equipment, and routine waste management practices such as removal of lead, polychlorinated biphenyls, and asbestos. In addition, some demolition of support buildings and structures is proceeding in advance of the NTCRA. It is important to understand that a substantial amount of work will have been completed, prior to finalization of this Action Memorandum.

The purpose of the NTCRA process is to determine:

- The final end state of the TRA-642 ETR reactor building abovegrade and belowgrade structure

- $\quad$ The final disposition of the ETR vessel

- The risks to human health and the environment associated with leaving contamination at the ETR Complex.

The IDAHO CERCLA Disposal Facility (ICDF) is the preferred disposal location for wastes meeting the ICDF Waste Acceptance Criteria (DOE-ID 2006b). For wastes eligible for disposal as solid wastes, the Central Facilities Area (CFA) Industrial Waste Landfill will be utilized for wastes generated 
during decommissioning activities at the ETR Complex. When the decommissioning involves management and/or generation of wastes subject to regulation under the Idaho Hazardous Waste Management Act/Resource Conservation and Recovery Act (HWMA/RCRA), these wastes will be addressed pursuant to requirements of those regulations.

Performance of this removal action will place the facilities in a configuration that is protective of human health and the environment. Without decommissioning the ETR Complex, a potential threat of release of hazardous substances exists and, without action, adverse threats to human health and the environment eventually could occur. As the lead agency, DOE has determined that a removal action is an appropriate means to accomplish the final end state and achieve environmental review requirements. Both the Idaho Department of Environmental Quality (DEQ) and the EPA concur that a NTCRA is warranted to place these facilities in a configuration that is protective of human health and the environment.

\section{BACKGROUND AND FACILITY DESCRIPTIONS}

This section provides summary background information and a description of the ETR Complex. It identifies previous and ongoing closure and cleanup activities, including a description of the buildings and structures addressed in this Action Memorandum and additional information relevant to the scope of this document. This section also provides a summary of the radiological and nonradiological characterization of the ETR Complex.

\subsection{Site Description and Background}

\subsubsection{Idaho National Laboratory Site and Idaho Cleanup Project}

The INL Site, managed by DOE, is located $51 \mathrm{~km}(32 \mathrm{mi})$ west of Idaho Falls, Idaho, and occupies $2,305 \mathrm{~km}^{2}\left(890 \mathrm{mi}^{2}\right)$ of the northeastern portion of the Eastern Snake River Plain. In 1949, the U.S. Atomic Energy Commission established the INL Site, which was called the National Reactor Testing Station at that time, for the purpose of conducting nuclear energy research and related activities. It was designated the Idaho National Engineering Laboratory in 1974 and then the Idaho National Engineering and Environmental Laboratory in 1997. In 2005, to better focus the laboratory's missions, DOE established the Idaho Cleanup Project to bring the environmental management mission to completion, and redesignated the laboratory as the INL to better reflect the new research directions.

DOE's Idaho Operations Office (DOE-ID) controls all land within the INL Site. Public access is restricted to public highways, sponsored tours, special-use permits, and the Experimental Breeder Reactor I National Historic Landmark. In addition, DOE-ID is cognizant of the Shoshone-Bannock tribal members' need for access to areas on the INL Site for cultural and religious purposes.

The INL Site is located primarily in Butte County; however, it also occupies portions of Bingham, Bonneville, Clark, and Jefferson counties. The 2000 census indicated the following populations for cities in the region: Idaho Falls-50,730; Pocatello-51,466; Blackfoot-10,419; Arco-1,026; and Atomic City-25.

Surface water flows on the INL Site consist mainly of three streams draining intermountain valleys to the north and northwest of the INL Site: (1) the Big Lost River, (2) the Little Lost River, and (3) Birch Creek. All of the channels terminate on the INL Site. Flows from Birch Creek and the Little Lost River seldom reach the INL Site because of irrigation withdrawals upstream. The Big Lost River and Birch Creek may flow onto the INL Site before the irrigation season or during high-water years, but the terminal reaches are usually dry. In those few wetter years when the Big Lost River carries water to the end of its channel, the water sinks into the ground. 
The physical characteristics, climate, flora and fauna, demography, and cultural resources of the INL Site and RTC area are further described in the Final Record of Decision for TRA Operable Unit (OU) 2-13 (DOE-ID 1997).

\subsubsection{Reactor Technology Complex Area}

The RTC is shown in Figure 1 and has served to house high-neutron-flux nuclear reactors and to test the effect of irradiation upon materials, fuels, and equipment. The complex was established in the early 1950s with the development of the Materials Testing Reactor (which is located in the TRA-603 building). Two other major reactors followed: the ETR, which is located in the TRA-642 building, and the Advanced Test Reactor, which is located in TRA-670. Removal of the fuel rods from Materials Testing Reactor and ETR began soon after reactor operations ceased, in 1970 and 1981, respectively. Only the Advanced Test Reactor is currently operational.

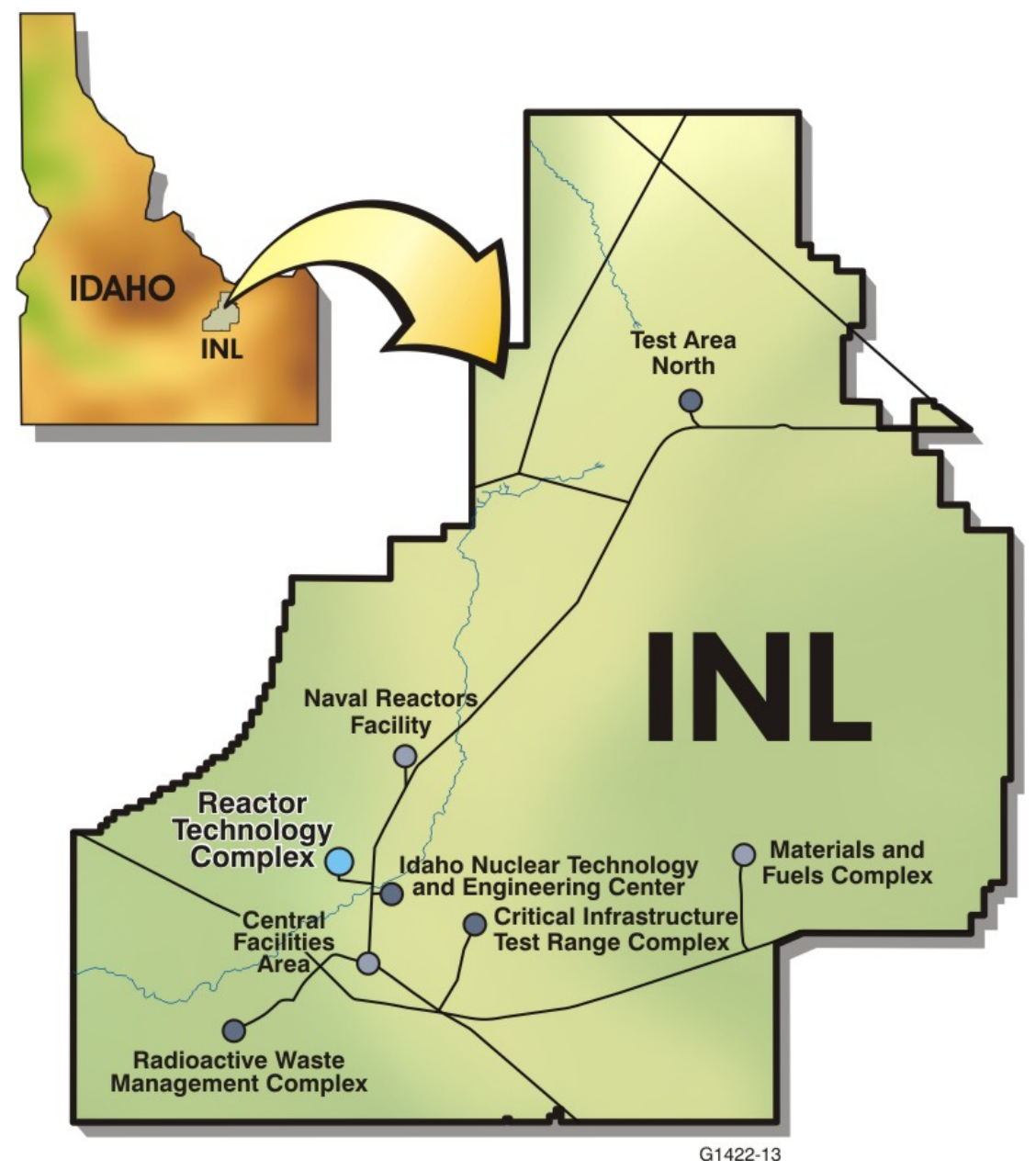

Figure 1. Map of the Idaho National Laboratory Site showing the location of the Reactor Technology Complex and other major facilities. 


\subsubsection{Engineering Test Reactor Complex}

The scope of the EE/CA included an evaluation of the risks to human health and the environment if contamination is left in place at the ETR Complex to determine the appropriate final end state of the complex. This section describes the buildings and structures where radionuclides and nonradiological constituents included in the contaminant source terms used in the risk evaluations reside. This section also includes some operational history and history of past deactivation and decommissioning activities that have taken place associated with those ETR Complex buildings and structures. Many of the aboveground structures have already been demolished; the EE/CA evaluated contaminants that may exist in the belowground structures.

The ETR Complex (Figure 2) first became operational in 1957. At the time it entered service, it was the largest, most advanced nuclear fuels and materials test reactor in the United States at $175 \mathrm{MWth}$ (megawatt thermal). After initial testing of the reactor, full power operation was achieved in 1958. In 1972, a decision was made to have the ETR support the DOE's breeder reactor safety program. Conversion of the reactor for this purpose started in May 1973. The new assignment focused on safety programs relating to reactor fuel, core design, and operation for the liquid metal fast-breeder reactor program. Figure 2 shows the locations of buildings and structures composing the ETR Complex.

Deactivation of the ETR Complex was initiated in December 1981. The neutron startup source was removed. Radioactive water was drained from the ETR vessel, primary coolant system, water loop experiment piping and vessels, both canal sections, degassing tank and associated piping, and resin tanks. Other water systems were drained, including the secondary coolant water (including heat exchangers), utility water, the two demineralized water systems (low and high pressure), and water in heating and cooling units. The fuel in the ETR, as well as irradiated fuel in the ETR storage canal, was removed and shipped to the Idaho Nuclear Technology and Engineering Center for storage.

2.1.3.1 Engineering Test Reactor Buildings and Structures. Buildings and structures that make up the ETR Complex and their planned end state are described below.

2.1.3.1.1 ETR Reactor Building (TRA-642)-The aboveground portions of the reactor building are to be demolished to below ground surface and the resultant demolition material may be used as backfill or disposed of in accordance with the applicable disposal site waste acceptance criteria (WAC). Materials left in place include inert, nonputrescible material located below the ground surface, such as piping, equipment, electrical conduit, utility systems, structural steel, and other residual clean or contaminated materials with low-level radioactive and/or chemically hazardous substances that do not present an unacceptable risk to human health or the environment. Much, if not all, of the regulated hazardous wastes will be removed. More than $99.999 \%$ of the radiological inventory of the ETR Complex resides in the ETR vessel; the remaining radiological constituents are located on surfaces and in pipes associated with the complex buildings and structures. 


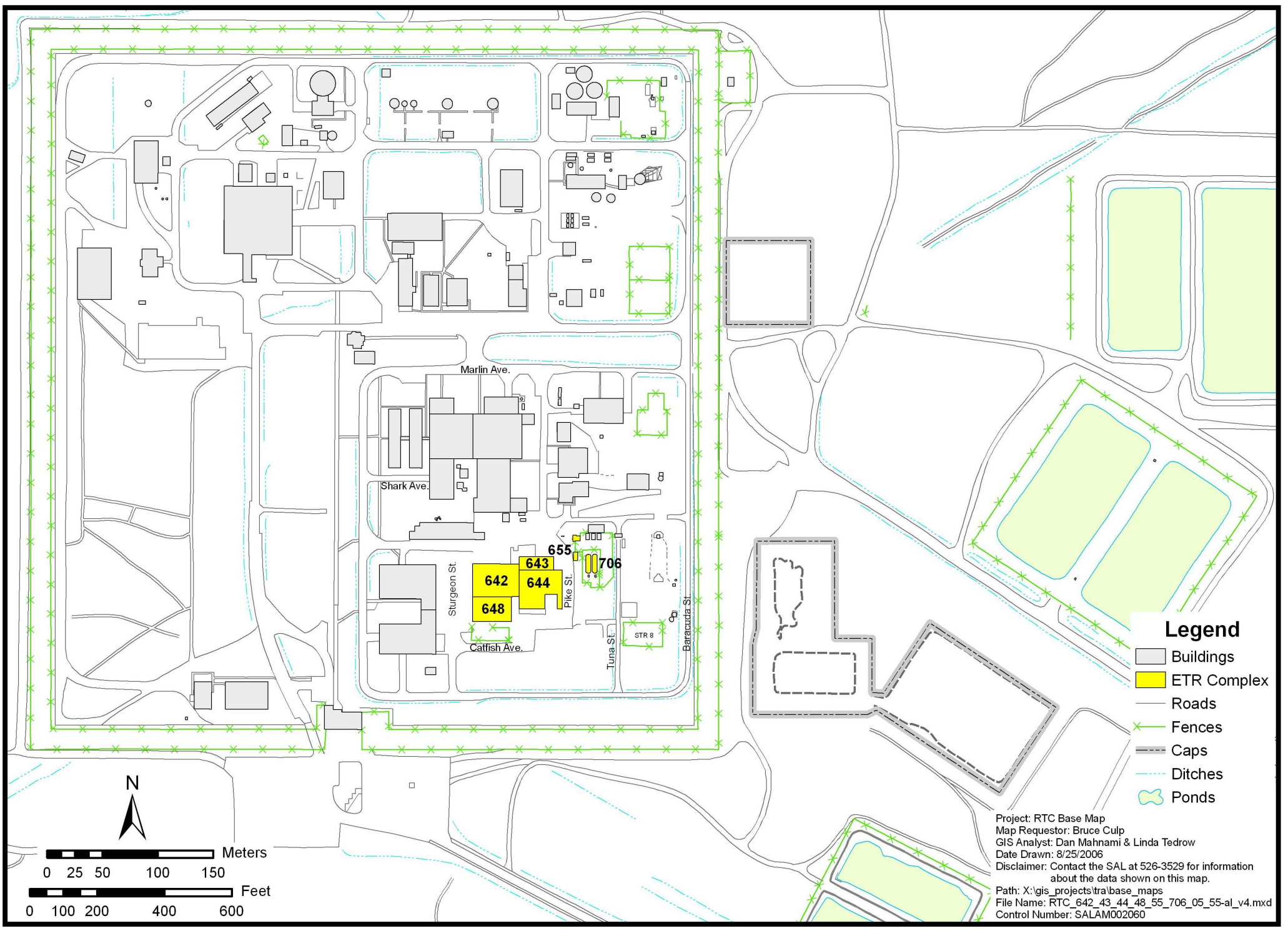

Figure 2. Map of the Reactor Technology Complex with the Engineering Test Reactor Complex highlighted. 
2.1.3.1.1.1 ETR Vesse/-The ETR vessel is a multidiameter, cylindrical vessel approximately $36 \mathrm{ft}$ in height and $12 \mathrm{ft}$ in diameter at the top, reducing down to $7 \mathrm{ft}$ in diameter at the bottom (Figure 3). As stated above, all fuel has been removed from the ETR vessel. Major internal components remaining in the vessel include the control rod guide tubes, control rod sections, aluminum and beryllium reflector, grid plate, and four in-pile tubes. The vessel also contains miscellaneous fillers, adapters, and plugs. The ETR vessel with the internal components weighs approximately 82 tons and it is planned to partially grout it to stabilize the internals. Similar to its installation in 1956 (Figure 3), the vessel will be lifted from the reactor building and placed on a transport truck for disposal at the ICDF. Once placed in the disposal cell at ICDF, the remainder of the void spaces in the vessel will be grouted in accordance with the ICDF WAC.

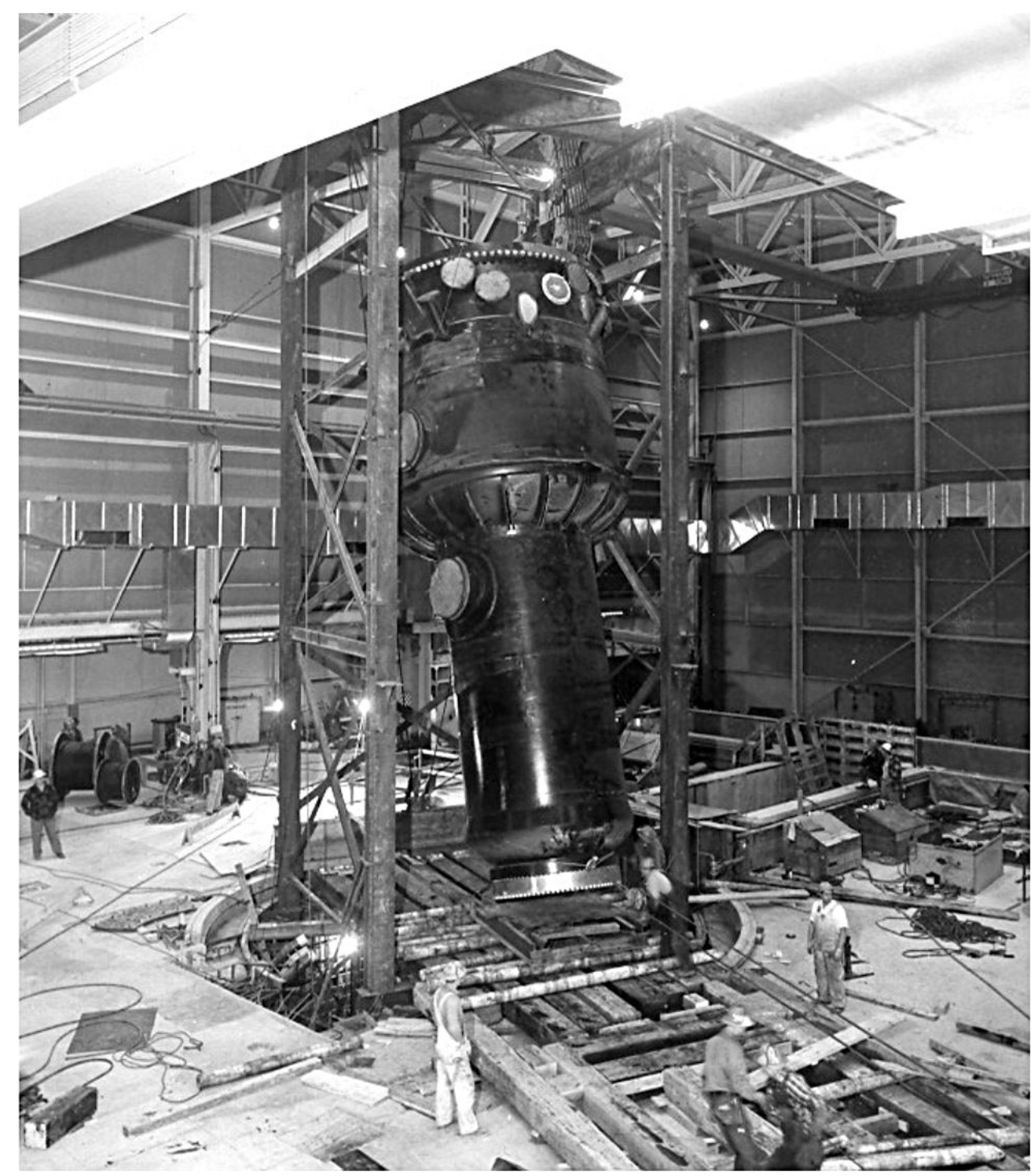

Figure 3. Engineering Test Reactor vessel installation in 1956. 
2.1.3.1.2 Experiment Cubicles-The basement is subdivided into a number of cubicles. Cubicle walls and the wall surrounding the ETR vessel are high-density concrete (i.e., contains magnetite). Other walls are standard concrete. Most of the piping and tanks have been removed from the cubicles along with the radiological contamination associated with those components. The walls and floors of cubicles are either removed, decontaminated, or sealed with a paint-on sealing material or epoxy paint.

2.1.3.1.3 Warm and Hot Waste Pits-Two unlined pits were built below the basement floor of the ETR reactor building. One of these, referred to as the hot waste pit, houses a 1,000-gal cold waste tank and a 500-gal hot waste tank. The hot waste tank was removed in 2005 as part of a Voluntary Consent Order (VCO) (DEQ 2000) closure. The other unlined pit, referred to as the warm waste pit, holds a 5,000-gal warm waste tank. These pits are located just inside the north wall of the reactor building. The remaining warm and cold waste tanks will be drained of any residual liquids and grouted in place. The vaults that hold the tanks will also be grouted.

\subsubsection{Engineering Test Reactor Compressor Building (TRA-643). TRA-643 was} demolished to below ground surface. Hazardous wastes and asbestos were removed and disposed of prior to demolition.

\subsubsection{Engineering Test Reactor Heat Exchanger Building (TRA-644). TRA-644 was} demolished to below ground surface. Hazardous wastes and asbestos were removed and disposed of prior to demolition. The heat exchangers, including most of the associated secondary and primary coolant piping, were removed and disposed of prior to demolition. The secondary pump pit was backfilled with clean fill.

\subsubsection{Other Engineering Test Reactor Complex Structures. Several smaller ancillary} structures at the ETR Complex supported reactor operations. These structures are comprised of the following:

- $\quad$ TRA-648-Electrical Building: The TRA-648 electrical building housed the major electrical equipment for the ETR facility. Equipment remaining in the building includes switchgear, Emergency Diesel Generator No. 1, five motor-generator units, and a battery bank.

The hazardous wastes and asbestos were removed from this building during the deactivation activities. The basement areas of TRA-648 contain a cable vault that held electrical cables and components and a fan room that housed the large blowers that provided ventilation. Small areas of loose and fixed contamination remain in the basement areas of TRA-648. The building will be demolished to below ground surface.

- $\quad$ TRA-706-Delay Tank Vault and Delay Tanks: This underground vault, located to the northeast of the TRA-643 compressor building, houses the delay tanks. The delay tanks are baffled tanks that were used to delay exhaust flow, allowing for the radioactive decay of short-lived radionuclides in the exhaust air. The tanks are $20 \mathrm{ft}$ below ground surface and contain low levels of radiological constituents. These tanks and the vault they sit in will be grouted in place.

- $\quad$ General Electric Experimental Loop (GEEL) Pipe Tunnel: The GEEL tunnel extends northeast from the reactor core. This tunnel was installed to allow ducts from the GEEL to exit the reactor building. The tunnel begins beneath the reactor building basement floor, runs under the annulus gas system cubicle, then underground north and east of the reactor building, and ends at the delay tanks. Hazardous wastes have been removed from the GEEL tunnel. The GEEL tunnel and associated Loop 99 will be grouted in place. 
- $\quad$ TRA-704, TRA-705, and TRA-755 Filter Pits: The filter pits contained large air filters that filtered the air in the exhaust systems from ETR-642 cubicles prior to it being exhausted from the ETR stack. The filters have been removed and disposed of and the unlined concrete vaults will be demolished to grade or below grade and backfilled or grouted as necessary.

\subsection{Previous Closure/Cleanup Activities at the ETR Complex}

\subsubsection{Comprehensive Environmental Response, Compensation, and Liability Act Activities at the Reactor Technology Complex}

The CERCLA final ROD for TRA OU 2-13 (DOE-ID 1997) and the Explanation of Significant Differences (DOE-ID 2000) selected a remedy for the cleanup of identified contaminated soil at the RTC. Remedies also were selected for the warm waste pond, perched water system, chemical waste pond, and sewage leach pond. Remedial actions specified by the ROD (DOE-ID 1997) have been completed at Waste Area Group 2 and, as required under CERCLA (42 USC $\S 9601$ et seq.) whenever contamination is left in place, institutional controls have been implemented for residual contaminants left in place at concentrations that would not allow for unrestricted use or access. Fifteen sites were found to require institutional controls to ensure adequate protection of human health and the environment. The Explanation of Significant Differences (DOE-ID 2000) discusses implementation, maintenance, and monitoring of institutional controls at each RTC site in detail.

Groundwater monitoring under CERCLA has been ongoing at the RTC in accordance with the requirements of the OU 2-12 and OU 2-13 RODs (DOE-ID 1992, 1997). On October 7, 1991, the EPA designated the Snake River Plain Aquifer (SRPA) a sole-source aquifer under the Safe Drinking Water Act (42 USC $\S 300 f$ et seq.). The SRPA and perched water beneath the RTC are monitored extensively, because changes in these sites could be indicative of the effectiveness of the remedies in place at the OU 2-13 sites or could indicate the occurrence of a new release.

\subsubsection{Voluntary Consent Order Activities}

The VCO Program was responsible for characterizing many of the support systems associated with the ETR that may have included RCRA (42 USC $\S 6901$ et seq.) hazardous wastes. These included the waste systems (hot, warm, and cold), the ETR vessel, the primary cooling system, the experimental water loop systems, the water makeup system for the M3/P7 experimental loops, the Sodium Loop Safety Facility helium cooling system, the experimental air system, the GEEL system, and the diesel generator system. All these systems were either characterized in accordance with HWMA (Idaho Code § 39-4401 et seq.) and RCRA regulations or verified as empty process/product tanks. All other VCO systems at the ETR Complex have undergone HWMA/RCRA closure.

The secondary pipe pit sump (TRA-644-48) was characterized as nonhazardous per RCRA regulations; however, the sump was identified as a potential release source of 40 CFR 261, Appendix VIII, constituents to the environment. Including this secondary pipe pit in the EE/CA and Action Memorandum satisfies the need for preparing and submitting this as a potential new release site under the Federal Facility Agreement and Consent Order.

\subsubsection{Other Activities at the ETR Complex}

Deactivation activities proceeded in advance of the NTCRA Action Memorandum. In addition to the deactivation activities, utility isolations and demolition of buildings and support structures is ongoing. Prior to demolition of buildings and structures, the following will have been performed: 
1. Hazardous Waste Removal: Hazardous waste-such as acidic or caustic material, mercury vapor lamps and fluorescent bulbs, lead shielding, circuit boards containing lead and/or silver soldering, and waste regulated under the Toxic Substances Control Act (TSCA) (15 USC § 2601 et seq.) such as polychlorinated biphenyl (PCB) articles and equipment (e.g., transformers, capacitors, and fluorescent lighting ballasts might contain PCBs) - is removed and disposed of. Other hazardous and toxic waste may be removed during NTCRA activities, as discovered during performance of these activities.

2. Asbestos Abatement Activities: Friable asbestos that might be found in pipe and tank/vessel insulation, fire doors, transite panels, and other potential asbestos-containing material, is removed as required under 40 CFR 61.145, "Standard for Demolition and Renovation."

3. Removal of Other Support Systems and Components from the ETR Complex: These activities include draining or emptying systems containing liquids; removing electrical cabinets, hoods, sinks, mixing tanks, and counters; and deenergizing and isolating utilities and reconfiguring those systems (as necessary) to support continuing RTC operations. In addition, chlorofluorocarbons used as refrigerants will be removed in accordance with the requirements of Section 609 of the Clean Air Act (42 USC $§ 7401$ et seq., as amended).

\section{THREAT TO PUBLIC HEALTH, WELFARE, AND/OR THE ENVIRONMENT}

The source of contamination at each of the buildings or structures addressed by this Action Memorandum has been characterized or estimated based on process knowledge and using conservative assumptions. In general, contamination at these facilities resulted from activities associated with research, testing, and processing of nuclear materials. Various resources were used to help identify the hazardous substances and the nature and extent of contamination in the facilities. These resources included historical operations information, process knowledge, radiological survey reports, radiation occurrence reports, facility assessment reports, personnel interviews, facility characterization reports, vulnerability assessments, inspections, walkdowns, and knowledge of construction materials.

To the extent practicable, hazardous substances - including lead, mercury, and PCBs - have been or will be removed from the facilities. However, residual contamination may remain on facility surfaces, in piping and ductwork, and in structural materials.

The major contaminants of concern (COCs) within the buildings and structures subject to this removal action are radionuclides, which are known carcinogens. Radiological contamination outside of the ETR vessel ranges from contaminated to noncontaminated, with the ETR vessel containing over $99 \%$ of the radioactive material inventory in the ETR Complex.

The "National Oil and Hazardous Substance Pollution Prevention Contingency Plan," 40 CFR 300.415(b)(2), establishes factors to be considered in determining the appropriateness of a removal action. Those factors include the following:

- $\quad$ Actual or potential exposure to nearby human populations, animals, or the food chain from hazardous substances, pollutants, or contaminants

- Weather conditions that may cause hazardous substances, pollutants, or contaminants to migrate or be released 
- Hazardous substances or pollutants in drums, barrels, tanks, or other bulk storage containers that may pose a threat of release.

Hazardous substances, including radionuclides, are present within the equipment, structures, and ETR vessel. If the ETR buildings are not properly maintained in the future, potential releases could occur that may pose an unacceptable risk to receptors. The external radiation, inhalation, and ingestion risks to Site workers, the public, and ecological receptors associated with potential releases of contamination justify a NTCRA.

\section{ENDANGERMENT DETERMINATION}

As the ETR Complex buildings and structures continue to age, the threat of substantial release of radiological and hazardous substances increases with time, and containing these materials and preventing them from being released to the environment becomes more difficult. The surveillance and maintenance $(\mathrm{S} \& \mathrm{M})$ activities required to confine the hazardous substances may increase the risk of potential exposure to personnel.

The potential exposure to workers and wildlife, the potential threat of future releases, and the substantial risks associated with the radiological and hazardous substances at the facilities addressed by this Action Memorandum justify use of CERCLA removal action authority in accordance with Section 300.415(b)(2) of the "National Oil and Hazardous Substances Pollution Contingency Plan." Actual and/or threatened releases of hazardous substances from these facilities have the potential to present a threat to public health and/or the environment.

\subsection{Removal Action Objectives}

The removal action objective (RAO) for this NTCRA is to perform final decommissioning of the ETR Complex consistent with the OU 2-13 RAOs to achieve the following:

- Inhibit direct exposure to radionuclide COCs that would result in a total excess cancer risk greater than 1 in 10,000 to 1 in 1,000,000 for current and future workers and future residents

- $\quad$ Inhibit ingestion of radionuclide and nonradiological COCs by all affected exposure routes (including groundwater, soil, and homegrown produce ingestion) that would result in a total excess cancer risk greater than 1 in 10,000 to 1 in $1,000,000$ or a hazard index of 1 or greater for current and future workers and future residents

- Inhibit adverse effects to flora and fauna — as determined from the ecological risk evaluationfrom COCs in the soil, surface water, and air.

Although decommissioning the ETR Complex is not specifically addressed in the ROD (DOE-ID 1997), these removal action objectives are consistent with the RAOs for contaminated soil established in that document. The removal action objectives also are predicated on the current and future land uses established in the ROD (DOE-ID 1997) for the RTC area, which include industrial land use until at least 2095 and the potential for residential land use thereafter. Actions conducted under this NTCRA would be reviewed with DEQ and EPA for continued protectiveness during the Site-wide CERCLA five-year review process prescribed under the Federal Facility Agreement and Consent Order for the Idaho National Engineering Laboratory (DOE-ID 1991). 


\subsection{Engineering Evaluation/Cost Analysis}

Engineering Evaluation/Cost Analysis for Decommissioning of the Engineering Test Reactor Complex (DOE-ID 2006a) is available through the Administrative Record for the removal action and can be found at the following internet address: http://ar.inel.gov.

The four alternatives considered in the ETR EE/CA for the ETR Complex NTCRA are discussed in the following sections.

\subsubsection{Alternative 1-No Action, Continued Surveillance and Maintenance}

Under the no action alternative, no removal action would be conducted on the ETR vessel and there would be no removal of hazardous substances beyond what is being done under the VCO (DEQ 2000) and deactivation activities. Current S\&M activities would continue. The no action alternative is included for completeness and comparative purposes.

Alternative 1 only defers taking further action upon the ETR Complex to a future date and does not address the potential for adverse threat to human health and potential threat of release of hazardous substances to the environment. It is not recommended for these reasons.

\subsubsection{Alternative 2-Grouting ETR Vessel in Place}

For Alternative 2, the ETR vessel would be filled with grout and the aboveground portions of the vessel would be encapsulated in a concrete monolith. The aboveground reactor building would be demolished. Belowgrade structures and systems, including piping, utility systems, and structural steel, would be abandoned in place. In addition, residual radioactive materials in the ETR Complex remaining after decommissioning and demolition activities are complete would remain in place and would be managed under the Site-wide Institutional Control Program. Void spaces would be grouted as necessary and/or backfilled as practicable using inert demolition waste from the above grade structures and clean backfill materials. Alternative 2 grouts the ETR vessel in place. Institutional controls such as barriers and groundwater monitoring would need to be maintained indefinitely at ETR to address wastes that would remain in place.

As prescribed in the OU 2-13 ROD, very conservative future land use assumptions were used to develop the risk analysis for the ETR Complex. The results of the risk assessment indicate an unacceptable risk would exist for this hypothetical future resident. Therefore, Alternative 2 does not meet the CERCLA threshold criteria of protecting human health and the environment, and thus this alternative is not recommended as an appropriate response action.

\subsubsection{Alternative 3-Removal and Disposal of ETR Vessel at an On-Site Disposal Facility}

Alternative 3 would include removal and disposal of the ETR vessel with vessel internal components intact at an on-Site disposal facility such as the ICDF or the Radioactive Waste Management Complex (RWMC). The reactor building would be demolished to ground surface; structures and systems below ground surface consisting of inert materials such as piping, tanks, structural metal, and utility systems, would be abandoned in place. Residual radioactive materials in the ETR Complex remaining after decommissioning and demolition activities are completed would stay in place and would be managed under the Site-wide Institutional Control Program. Void spaces would be backfilled as practicable, including the void left by removal of the ETR vessel. Backfill would consist of grout, as necessary, and/or inert demolition waste from the above grade structures and clean backfill materials. As 
required by the OU 3-13 ROD, monitoring and maintenance will be conducted at the ICDF throughout the operational and post closure periods.

Placement of the ETR vessel at the ICDF is more appropriate than leaving the ETR vessel in place at the RTC under Alternative 2. The ICDF uses less conservative assumptions for establishing the future land use, as described in the OU 3-13 ROD, than is prescribed in the OU 2-13 ROD. Instead, the risk assessment for the ICDF assumes that land use controls will prohibit future residential use indefinitely, so there was no evaluation of risks to a hypothetical future resident. Both potential risks to industrial workers and impacts to the aquifer were evaluated for the ICDF and found to be acceptable. Additionally, with the reactor vessel removed as proposed under Alternative 3, risks to a future hypothetical resident at the RTC were determined to be acceptable, using the exposure assumptions described in the preceding section. Therefore, Alternative 3 meets the threshold criteria of protecting human health and the environment and is an appropriate response action.

Compared to Alternative 4, Alternative 3 provides the most protection for the worker and costs less. Disposal at the ICDF rather than the RWMC has several advantages including that it is a lined disposal facility and that transportation across a public highway (US Highway 20) would not be required. Also, the RWMC is an ongoing CERCLA cleanup site; therefore disposal of additional CERCLA waste at this facility is deemed inappropriate and should be minimized.

\subsubsection{Alternative 4-Removal and Disposal of ETR Vessel at an Off-Site Disposal Facility}

Alternative 4 results in the same end state for the ETR Complex as Alternative 3. The ETR vessel is disposed of at an off-Site disposal facility. To allow for disposal off Site, the vessel has to meet Department of Transportation packaging and shipping requirements. To meet these requirements, the vessel would be separated (cut) into the upper vessel tank and the lower vessel tank. This lower vessel tank contains the majority of the radioactive components and would be packaged to meet Department of Transportation packaging requirements. Both top and bottom sections would be transported separately to an off-Site disposal facility.

Compared to Alternative 3, Alternative 4 poses greater risk for the worker and costs more; however, Alternative 4 is ranked somewhat higher in long-term protectiveness of the groundwater below the ICDF than Alternative 3 as it does not add to the ICDF source term.

\subsection{Selected Alternative}

The alternatives evaluated in the engineering evaluation/cost analysis are discussed in Section 4.2. The selected alternative is Alternative 3 and includes removing and disposing of the ETR vessel at the INEEL CERCLA Disposal Facility (ICDF) and demolishing the reactor building to ground surface.

The selected alternative meets the remedial action objectives regarding long-term risk, minimizes short-term worker risk and radiation exposure, reduces the footprint of waste sites at the INL, is cost effective, and provides a safe and stable configuration that is environmentally sound. The end state provided by Alternative 3 is consistent with the DOE goal to minimize long term surveillance and maintenance costs by reducing the footprints and consolidating waste from contaminated facilities.

The ETR vessel meets the ICDF WAC and would be transported and disposed of as low-level radioactive waste at the ICDF. Any remaining voids in the vessel would be filled with grout at the disposal site. The aboveground portions of the reactor building would be demolished to below ground surface and the resultant demolition material could be used as backfill or disposed of in accordance with 
the applicable disposal site WAC. Materials left in place include inert, nonputrescible material located below the ground surface, such as piping, equipment, electrical conduit, utility systems, structural steel, and other residual clean or contaminated materials with low-level radioactive and/or chemically hazardous substances that do not present an unacceptable risk in accordance with the RAOs for the ROD (DOE-ID 1997) and the Explanation of Significant Differences (DOE-ID 2000). Excavations and remaining belowgrade structures would be grouted as necessary and backfilled to grade. Clean soil would cover the locations of the ETR Complex buildings and structures.

\subsection{Compliance with Environmental Regulations, Including Those That Are Applicable or Relevant and Appropriate Requirements}

Section 121 of CERCLA (42 USC § 9621) requires the responsible CERCLA-implementing agency to ensure that the substantive standards of HWMA/RCRA and other applicable laws will be incorporated into the federal agency's design and operation of its long-term remedial actions and into its more immediate removal actions. DOE-ID is the implementing agency for this NTCRA. Both DEQ and EPA concur that a NTCRA is warranted to protect human health and the environment.

Table 1 lists the proposed applicable or relevant and appropriate requirements (ARARs) that have been identified for this removal action. These ARARs are a compilation and expansion of those identified in the ROD (DOE-ID 1997). The ARARs list is based on several key assumptions:

- $\quad$ Any residual contamination left in place will meet the RAOs established in the ROD (DOE-ID 1997).

- $\quad$ Liquid waste (e.g., radioactive water) is assumed to have been removed from the ETR Complex prior to initiation of the NTCRA. The liquid waste will have been previously addressed through the VCO Program and other regulatory activities to resolve potential compliance issues with provisions of the HWMA/RCRA. Any residual liquids discovered during decommissioning activities will be disposed of in accordance with the receiving disposal facility's WAC.

- The majority of lead shielding will be removed from the ETR Complex prior to initiation of the NTCRA through other regulatory activities intended to place the facility in an environmentally safe condition. However, some lead may remain following these activities, which may require management under the scope of the NTCRA as CERCLA waste. Removed lead that cannot be recycled or reclaimed shall be declared a hazardous waste or mixed low-level waste, managed in accordance with the substantive requirements of the HWMA/RCRA and will be disposed of at an off-Site disposal facility in accordance with the disposal facility WAC.

- $\quad$ Management of CERCLA waste generated during the removal action would be subject to meeting the ICDF's WAC (DOE-ID 2005). Noncontaminated wastes generated during the CERCLA activities may be eligible for disposal at the CFA landfill.

- If decontamination liquids are generated, they will be disposed of at the ICDF evaporation ponds in accordance with the approved WAC. 
Table 1. Summary of applicable or relevant and appropriate requirements for the Engineering Test Reactor Complex non-time-critical removal action.

\begin{tabular}{|c|c|c|}
\hline Requirement (Citation) & ARAR Type & Comments \\
\hline \multicolumn{3}{|l|}{ Clean Air Act and Idaho Air Regulations } \\
\hline “Toxic Substances,” IDAPA 58.01.01.161 & A & $\begin{array}{l}\text { Applies to any toxic substances emitting during implementation of the } \\
\text { removal action. }\end{array}$ \\
\hline$<10$ mrem/yr, 40 CFR 61.92, "Standard" & A & Applies to the waste-handling activities. \\
\hline "Emission Monitoring and Test Procedures," 40 CFR 61.93 & $\mathrm{~A}$ & Applies to the waste-handling activities. \\
\hline “Compliance and Reporting," 40 CFR 61.94(a) & $\mathrm{A}$ & Applies to the waste-handling activities. \\
\hline "Standard for Demolition and Renovation," 40 CFR 61.145 & A & $\begin{array}{l}\text { Applies to any asbestos-containing materials removed during the } \\
\text { decommissioning. }\end{array}$ \\
\hline $\begin{array}{l}\text { "Rules for Control of Fugitive Dust," and "General Rules," } \\
\text { IDAPA 58.01.01.650 and .651 }\end{array}$ & A & Applies to the waste-handling activities. \\
\hline \multicolumn{3}{|l|}{ Idaho Solid Waste Facilities Act } \\
\hline $\begin{array}{l}\text { "Applicable Requirements for Tier II Facilities," } \\
\text { IDAPA 58.01.06.012 }\end{array}$ & A & Applies to disposal of solid wastes at the CFA landfill. \\
\hline \multicolumn{3}{|l|}{ RCRA and Idaho HWMA } \\
\hline \multicolumn{3}{|l|}{ Generator Standards: } \\
\hline \multicolumn{3}{|c|}{ "Standards Applicable to Generators of Hazardous Waste," IDAPA 58.01.05.006, and the following, as cited in it: } \\
\hline "Hazardous Waste Determination,” 40 CFR 262.11 & $\mathrm{~A}$ & Applies to waste that would be generated during the removal action. \\
\hline \multicolumn{3}{|l|}{ General Facility Standards: } \\
\hline \multicolumn{3}{|c|}{$\begin{array}{l}\text { IDAPA 58.01.05.008, "Standards for Owners and Operators of Hazardous Waste Treatment, Storage, and Disposal Facilities," and the following, } \\
\text { as cited in it: }\end{array}$} \\
\hline “Temporary Units (TU),” 40 CFR 264.553 & A & $\begin{array}{l}\text { Waste may be treated or temporarily stored in a temporary unit prior to } \\
\text { disposal. }\end{array}$ \\
\hline "Staging Piles," 40 CFR 264.554 & A & Waste may be temporarily staged prior to disposal. \\
\hline "General Inspections Requirements," 40 CFR 264.15 & A & $\begin{array}{l}\text { Applies to a facility staging, storing, or treating hazardous waste prior to } \\
\text { transfer to the ICDF or an off-Site facility. }\end{array}$ \\
\hline "Preparedness and Prevention," 40 CFR 264, Subpart C & A & $\begin{array}{l}\text { Applies to a facility staging, storing, or treating hazardous waste prior to } \\
\text { transfer to the ICDF or an off-Site facility. }\end{array}$ \\
\hline
\end{tabular}


Table 1. (continued).

\begin{tabular}{|c|c|c|}
\hline Requirement (Citation) & ARAR Type & Comments \\
\hline $\begin{array}{l}\text { "Contingency Plan and Emergency Procedures," } \\
40 \text { CFR 264, Subpart D }\end{array}$ & A & $\begin{array}{l}\text { Applies to a facility staging, storing, or treating hazardous waste prior to } \\
\text { transfer to the ICDF or an off-Site facility. }\end{array}$ \\
\hline $\begin{array}{l}\text { "Disposal or Decontamination of Equipment, Structures, } \\
\text { and Soils," } 40 \text { CFR } 264.114\end{array}$ & A & $\begin{array}{l}\text { Applies to contaminated equipment used to remove, treat, or transport } \\
\text { hazardous waste. }\end{array}$ \\
\hline $\begin{array}{l}\text { "Use and Management of Containers," } \\
40 \text { CFR 264.171-178 }\end{array}$ & A & $\begin{array}{l}\text { Applies to containers used during the removal and treatment of hazardous } \\
\text { waste. }\end{array}$ \\
\hline \multicolumn{3}{|l|}{ Land Disposal Restrictions: } \\
\hline \multicolumn{3}{|c|}{ IDAPA 58.01.05.011, "Land Disposal Restrictions," and the following, as cited in it: } \\
\hline $\begin{array}{l}\text { "Applicability of Treatment Standards," } \\
40 \text { CFR } 268.40(\mathrm{a})(\mathrm{b})(\mathrm{e})\end{array}$ & A & $\begin{array}{l}\text { Applies to hazardous waste and secondary waste, if treatment is necessary } \\
\text { to meet the disposal facility's WAC or if treatment is required before } \\
\text { placement. }\end{array}$ \\
\hline $\begin{array}{l}\text { "Treatment Standards for Hazardous Debris," } \\
40 \text { CFR } 268.45\end{array}$ & A & $\begin{array}{l}\text { Applies to hazardous debris, if treatment is necessary to meet the disposal } \\
\text { facility's WAC or if treatment is required before placement. }\end{array}$ \\
\hline “Universal Treatment Standards," 40 CFR 268.48(a) & A & $\begin{array}{l}\text { Applies to nondebris hazardous waste and secondary waste, if treatment is } \\
\text { necessary to meet the disposal facility's WAC or if treatment is required } \\
\text { before placement. }\end{array}$ \\
\hline $\begin{array}{l}\text { "Alternative LDR Treatment Standards for } \\
\text { Contaminated Soil," } 40 \text { CFR } 268.49\end{array}$ & A & $\begin{array}{l}\text { Applies to contaminated soil, if treatment is necessary to meet the disposal } \\
\text { facility's WAC or if treatment is required before placement. }\end{array}$ \\
\hline \multicolumn{3}{|c|}{ IDAPA 58.01.05.016, "Standards for Universal Waste Management" } \\
\hline $\begin{array}{l}\text { "Standards for Large Quantity Handlers of Universal } \\
\text { Waste," } 40 \text { CFR } 273 \text { Subpart C }\end{array}$ & A & Applies to management of universal wastes. \\
\hline \multicolumn{3}{|l|}{ Idaho Groundwater Quality Rules } \\
\hline “Ground Water Quality Rule,” IDAPA 58.01.011 & A & $\begin{array}{l}\text { The waste-handling activities must prevent migration of contaminants from } \\
\text { the reactor complex that would cause the Snake River Plain Aquifer } \\
\text { groundwater to exceed applicable State of Idaho groundwater quality } \\
\text { standards in } 2095 \text { and beyond. }\end{array}$ \\
\hline \multicolumn{3}{|l|}{ TSCA } \\
\hline $\begin{array}{l}\text { "Decontamination Standards and Procedures: } \\
\text { Decontamination Standards," } 40 \text { CFR 761.79(b)(1) }\end{array}$ & A & $\begin{array}{l}\text { Applicable to decontamination of equipment with PCB contamination, if } \\
\text { PCB waste is generated. }\end{array}$ \\
\hline $\begin{array}{l}\text { "Decontamination Standards and Procedures: } \\
\text { Self-Implementing Decontamination Procedures," } \\
40 \text { CFR } 761.79(\mathrm{c})(1) \text { and }(2)\end{array}$ & A & $\begin{array}{l}\text { Applicable to decontamination of equipment with PCB contamination, if } \\
\text { PCB waste is generated. }\end{array}$ \\
\hline
\end{tabular}


Table 1. (continued).

\begin{tabular}{|c|c|c|}
\hline Requirement (Citation) & ARAR Type & Comments \\
\hline $\begin{array}{l}\text { "Decontamination Standards and Procedures: } \\
\text { Decontamination Solvents," } 40 \text { CFR } 761.79 \text { (d) }\end{array}$ & A & $\begin{array}{l}\text { Applicable to decontamination of equipment used to manage } \\
\text { PCB-contaminated waste, if PCB waste is generated. }\end{array}$ \\
\hline $\begin{array}{l}\text { "Decontamination Standards and Procedures: Limitation of } \\
\text { Exposure and Control of Releases," } 40 \text { CFR 761.79(e) }\end{array}$ & A & $\begin{array}{l}\text { Applicable to decontamination activities of equipment with } \\
\text { PCB-contaminated waste, if decontamination is performed. }\end{array}$ \\
\hline $\begin{array}{l}\text { "Decontamination Standards and Procedures: } \\
\text { Decontamination Waste and Residues," } 40 \text { CFR 761.79(g) }\end{array}$ & A & $\begin{array}{l}\text { Applicable to management of decontaminated waste and residuals from } \\
\text { PCB-contaminated equipment, if PCB waste is generated. }\end{array}$ \\
\hline \multicolumn{3}{|l|}{ Department of Transportation } \\
\hline $\begin{array}{l}\text { "Shippers-General Requirements for Shipments and } \\
\text { Packaging," } 49 \text { CFR } 173\end{array}$ & A & Applicable for packaging and transportation of the ETR vessel off the INL. \\
\hline \multicolumn{3}{|l|}{ To-Be-Considered Requirements } \\
\hline $\begin{array}{l}\text { "Radiation Protection of the Public and the Environment," } \\
\text { DOE Order 5400.5, Chapter } \operatorname{II}(1)(a, b)\end{array}$ & $\mathrm{TBC}$ & $\begin{array}{l}\text { Applies to the ETR Complex before, during, and after the removal action. } \\
\text { Substantive design and construction requirements would be met to keep } \\
\text { public exposures as low as reasonably achievable. }\end{array}$ \\
\hline “Radioactive Waste Management," DOE Order 435.1 & $\mathrm{TBC}$ & $\begin{array}{l}\text { Applies to the ETR Complex before, during, and after the removal action. } \\
\text { Substantive design and construction requirements would be met to protect } \\
\text { workers. }\end{array}$ \\
\hline $\begin{array}{l}\text { Region } 10 \text { Final Policy on the Use of Institutional Controls at } \\
\text { Federal Facilities (EPA 2006) }\end{array}$ & $\mathrm{TBC}$ & Applies to residual waste following completion of the removal action. \\
\hline \multicolumn{3}{|c|}{$\begin{array}{l}\text { ARAR }=\text { applicable or relevant and appropriate requirement } \\
\text { CERCLA = Comprehensive Environmental Response, Compensation, and Liability Act } \\
\text { CFR = Code of Federal Regulations } \\
\text { DOE = U.S. Department of Energy } \\
\text { EPA = U.S. Environmental Protection Agency } \\
\text { ETR = Engineering Test Reactor } \\
\text { ICDF = Idaho CERCLA Disposal Facility } \\
\text { IDAPA = Idaho Administrative Procedures Act } \\
\text { PCB = polychlorinated biphenyl } \\
\text { RCRA = Resource Conservation and Recovery Act } \\
\text { TSCA = Toxic Substances Control Act }\end{array}$} \\
\hline
\end{tabular}


- $\quad$ Debris generated during removal of the vessel might have paint that contains PCBs. If encountered, such waste may trigger substantive requirements of the TSCA (15 USC $\S 2601$ et seq.). Lead-contaminated paint also may be removed during recovery of the shielding lead, which would be subject to the substantive requirements of RCRA hazardous waste regulations. Nonhazardous waste would be disposed of at the ICDF, unless it can be demonstrated that it is eligible for disposal as solid waste at the CFA Landfill Complex. Removal is planned for the PCB-containing light ballasts from the building prior to this removal action. PCB-containing light ballasts are disposed at an off-site disposal site in accordance with the disposal site WAC.

- $\quad$ Asbestos-containing material, which is both friable and nonfriable, may be encountered incidental to performance of the NTCRA. Friable or regulated asbestos-containing material is subject to specific asbestos regulations and would be acceptable for disposal at the ICDF and/or, if not radiologically contaminated, at the CFA Asbestos Landfill. Regulated asbestos will be removed and disposed of as required by 40 CFR 61.150, "Standard for Waste Disposal for Manufacturing, Fabricating, Demolition, Renovation, and Spraying Operations." Undisturbed asbestos or asbestos found in high-radiation, high-contamination, and/or inaccessible locations greater than $10 \mathrm{ft}$ below the ground surface may be left in place.

- Mercury located in mercury fluorescent lamps is planned for removal prior to this removal action under other regulatory activities intended to place the facility in an environmentally safe condition, as are the mercury-containing electrical switches and lights. No mercury is expected to be present in the building substructure at the start of the removal action.

\subsection{Cultural Resources}

Section 106 of the National Historic Preservation Act of 1966 (NHPA) (16 USC $\S 470$ et seq.), as amended, requires agencies to consider the impact of undertakings on properties listed or eligible for listing in the National Register of Historic Places, and to consult with the Idaho State Historic Preservation Officer and other interested parties when impacts are likely. It also requires federal agencies to invite the Advisory Council on Historic Preservation to participate in consultation when impacts may be adverse.

The NHPA Section 106 process has been tailored to meet the unique needs of the INL Site. Section 110 of the NHPA directs federal agencies to establish programs to find, evaluate, and nominate eligible properties to the National Register of Historic Places, including previously unidentified historic properties that may be discovered during the implementation of a project (36 CFR 800). In addition, the Archaeological Resources Protection Act of 1979 (16 USC $\S 470 \mathrm{aa}-470 \mathrm{~mm}$ ), as amended, provides for the protection and management of archaeological resources on federal lands. Procedures and strategies to tailor these requirements to the unique needs of the INL Site are described in the INL Cultural Resource Management Plan (CRMP) (DOE-ID 2004b). The INL CRMP is implemented through a Programmatic Agreement between DOE-ID, the Idaho State Historic Preservation Officer, and the Advisory Council on Historic Preservation.

The ETR Complex is a historic property, eligible for nomination to the National Register of Historic Places. DOE-ID has made the decision to proceed with demolition of the ETR Complex. To mitigate the adverse impacts caused by such action, DOE-ID - through measures outlined in the INL CRMP - has committed to the preservation of the ETR history through the completion of a Historic American Engineering Record report. The ETR Historic American Engineering Record report will ultimately be accessioned into the Library of Congress' permanent collections. 
DOE is required to review as guidance the most current United States Fish and Wildlife Service list for threatened and endangered plant and animal species. DOE-ID determined that none of the alternatives would impact any threatened and endangered species and also determined that formal consultation with the United States Fish and Wildlife Service is not required for this action.

\subsection{Compliance with Disposal Facility Waste Acceptance Criteria}

Wastes generated through implementation of Alternative 3 will be dispositioned at appropriate on-Site or off-Site waste disposal facilities, in accordance with the WAC of those facilities. The CFA Industrial Waste Landfill will be utilized for those uncontaminated solid wastes generated during the ETR Complex decommissioning activities. The ICDF will be the preferred disposal location for contaminated wastes generated during the decommissioning that meet the ICDF WAC.

The ICDF is a state-of-the-art disposal facility designed and constructed with leachate collection and leak detection systems, with two 60-mil high-density polyethylene liners, and a 3-ft-thick clay bottom liner. The ICDF is an on-Site disposal facility that accepts CERCLA waste generated at the INL Site. Hazardous, mixed, low-level, asbestos, and Toxic Substances Control Act waste can be accepted for disposal at the ICDF (DOE-ID 2006b).

\section{PROJECT SCHEDULE}

This removal action is expected to begin the general decommissioning activities upon issuance of this Action Memorandum. Decommissioning of the ETR Complex is estimated to be completed by the end of calendar year 2008 .

\section{PROJECT COST}

Cost estimates were prepared for the alternatives evaluated in the EE/CA (DOE-ID 2006a). The estimates were prepared in accordance with $A$ Guide to Developing and Documenting Cost Estimates During the Feasibility Study (EPA 2000). Costs were calculated for both capital expenditures and future operation and maintenance expenses. In accordance with EPA guidance, the cost for the alternatives over time was calculated as present net worth costs, which are sometimes referred to as net present value, to represent the costs in 2006 dollars.

The cost estimate is based upon the best available information regarding the anticipated scope of the selected alternative. Changes in the cost elements are likely to occur as a result of new information and data collected during the engineering design and performance of the removal action. This is an orderof-magnitude engineering cost estimate that is expected to be within +50 to $-30 \%$ of actual project cost. The present-worth cost estimate for the selected alternative is $\$ 6,500,000$.

\section{EXPECTED CHANGE SHOULD ACTION BE DELAYED OR NOT TAKEN}

The expected change to the ETR Complex buildings and structures should action be delayed or not taken would be that the facilities would remain under administrative and institutional control. However, as the facilities continue to age, the threat of substantial release of radiological and hazardous substances increases with time, and containing these materials and preventing them from being released to the environment becomes more difficult. The S\&M activities required to confine the hazardous substances may increase the risk of potential exposure to personnel. If the action was delayed, continued 
expenditures for surveillance and maintenance costs would accrue during the time interval elapsed until final decommissioning activities are performed.

\section{STATUTORY AND REGULATORY AUTHORITY}

The proposed removal action is being undertaken by DOE-ID, as the lead agency, pursuant to CERCLA, Section 104(a), and Executive Order 12580, as recognized by Section 5.3 of the Federal Facility Agreement and Consent Order for the Idaho National Engineering Laboratory (DOE-ID 1991). In accordance with 40 CFR 300.415(j) and DOE guidance, on-Site removal actions conducted under CERCLA are required to meet ARARs to the extent practicable considering the exigencies of the situation. The DOE-ID will comply with the ARARs and the "to-be-considered" guidance as set forth in Section 4.4.

\section{OUTSTANDING POLICY ISSUES}

There are no outstanding policy issues.

\section{ENFORCEMENT}

DOE-ID is conducting this removal action as the lead agency under the authority of 40 CFR 300.5 , "Definitions," and 40 CFR 300.415(b)(1), "Removal Action."

\section{RECOMMENDATION}

DOE-ID recommends implementation of Alternative 3, "Removal and Disposal of the ETR Vessel at an On-Site Disposal Facility," with disposal at the ICDF. The ICDF is a state-of-the-art, multiple-lined, and monitored on-Site disposal facility that offers greater protection to human health and the environment than disposal at the unlined disposal cells at RWMC. The vessel would be filled with grout (as necessary) to stabilize vessel internals and reduce radiological dose. The ETR vessel would be transported and disposed of as low-level radioactive waste at the ICDF in full compliance with the ICDF WAC. Any remaining voids in the vessel would be filled with grout at the disposal site.

The aboveground portions of the reactor building would be demolished to below ground surface and the resultant demolition material may be used as backfill or disposed of in accordance with the applicable disposal site WAC. Materials left in place include inert, nonputrescible material located below the ground surface, such as piping, equipment, electrical conduit, utility systems, structural steel, and other residual clean or contaminated materials with low-level radioactive and/or chemically hazardous substances that do not present an unacceptable risk in accordance with the RAOs for the ROD (DOE-ID 1997) and the Explanation of Significant Differences (DOE-ID 2000). Excavations and remaining belowgrade structures will be backfilled to grade. Clean soil would cover the locations of the ETR Complex buildings and structures.

The recommended alternative meets the proposed RAOs regarding long-term risk, minimizes short-term worker risk and radiation exposure, is cost effective, and provides a safe and stable configuration that is environmentally sound. The DOE-ID also considers Alternative 3 compliant with ARARs. 


\section{PUBLIC PARTICIPATION}

Appendix A describes the public participation process and includes comments received and responses provided. Appendix B is the letter received from the INL Site Environmental Management Citizens Advisory Board documenting the recommendations and opposition to the selected alternative.

\section{REFERENCES}

36 CFR 800, 2004, "Protection of Historic Properties," Code of Federal Regulations, Office of the Federal Register, August 2004.

40 CFR 61.92, 2006, "Standard," Code of Federal Regulations, Office of the Federal Register, July 2006.

40 CFR 61.93, 2006, "Emission Monitoring and Test Procedures," Code of Federal Regulations, Office of the Federal Register, July 2006.

40 CFR 61.94, 2006, "Compliance and Reporting," Code of Federal Regulations, Office of the Federal Register, July 2006.

40 CFR 61.145, 2006, "Standard for Demolition and Renovation," Code of Federal Regulations, Office of the Federal Register, July 2006.

40 CFR 61.150, 2006, "Standard for Waste Disposal for Manufacturing, Fabricating, Demolition, Renovation, and Spraying Operations," Code of Federal Regulations, Office of the Federal Register, July 2006.

40 CFR 261, Appendix VIII, 2006, “Hazardous Constituents," Code of Federal Regulations, Office of the Federal Register, July 2006.

40 CFR 262.11, 2006, "Hazardous Waste Determination," Code of Federal Regulations, Office of the Federal Register, July 2006.

40 CFR 264, Subpart C, 2006, "Preparedness and Prevention," Code of Federal Regulations, Office of the Federal Register, July 2006.

40 CFR 264, Subpart D, 2006, “Contingency Plan and Emergency Procedures,” Code of Federal Regulations, Office of the Federal Register, July 2006.

40 CFR 264.15, 2006, "General Inspection Requirements," Code of Federal Regulations, Office of the Federal Register, July 2006.

40 CFR 264.114, 2006, "Disposal or Decontamination of Equipment, Structures and Soils," Code of Federal Regulations, Office of the Federal Register, July 2006.

40 CFR 264.171, 2006, "Condition of Containers," Code of Federal Regulations, Office of the Federal Register, July 2006.

40 CFR 264.172, 2006, "Compatibility of Waste with Containers," Code of Federal Regulations, Office of the Federal Register, July 2006. 
40 CFR 264.173, 2006, "Management of Containers," Code of Federal Regulations, Office of the Federal Register, July 2006.

40 CFR 264.174, 2006, "Inspections," Code of Federal Regulations, Office of the Federal Register, July 2006.

40 CFR 264.175, 2006, "Containment," Code of Federal Regulations, Office of the Federal Register, July 2006.

40 CFR 264.176, 2006, "Special Requirements for Ignitable or Reactive Waste," Code of Federal Regulations, Office of the Federal Register, July 2006.

40 CFR 264.177, 2006, "Special Requirements for Incompatible Wastes," Code of Federal Regulations, Office of the Federal Register, July 2006.

40 CFR 264.178, 2006, “Closure,” Code of Federal Regulations, Office of the Federal Register, July 2006.

40 CFR 264.553, 2006, “Temporary Units (TU)," Code of Federal Regulations, Office of the Federal Register, July 2006.

40 CFR 264.554, 2006, "Staging Piles," Code of Federal Regulations, Office of the Federal Register, July 2006.

40 CFR 268.40, 2006, “Applicability of Treatment Standards," Code of Federal Regulations, Office of the Federal Register, July 2006.

40 CFR 268.45, 2006, “Treatment Standards for Hazardous Debris," Code of Federal Regulations, Office of the Federal Register, July 2006.

40 CFR 268.48, 2006, "Universal Treatment Standards," Code of Federal Regulations, Office of the Federal Register, July 2006.

40 CFR 268.49, 2006, “Alternative LDR Treatment Standards for Contaminated Soil," Code of Federal Regulations, Office of the Federal Register, July 2006.

40 CFR 273, Subpart C, 2006, "Standards for Large Quantity Handlers of Universal Waste," Code of Federal Regulations, Office of the Federal Register, July 2006.

40 CFR 300, 2006, "National Oil and Hazardous Substances Pollution Contingency Plan," Code of Federal Regulations, Office of the Federal Register, August 2006.

40 CFR 300.415, 2006, "Removal Action," Code of Federal Regulations, Office of the Federal Register, August 2006.

40 CFR 761.79, 2006, "Decontamination Standards and Procedures," Code of Federal Regulations, Office of the Federal Register, June 2006.

49 CFR 173, 2006, "Shippers-General Requirements for Shipments and Packagings," Code of Federal Regulations, Office of the Federal Register, June 2006. 
15 USC $§ 2601$ et seq., 1976, “The Toxic Substances Control Act (TSCA) of 1976," United States Code, January 1, 1977.

16 USC § 470 et seq., 1966, "National Historic Preservation Act," United States Code, October 15, 1966.

16 USC § 470aa-470mm, 2002, “Archaeological Resources Protection Act," United States Code, January 22, 2002.

42 USC § 300f et seq., “Safe Drinking Water Act,” United States Code, December 1974.

42 USC $\S 6901$ et seq., 1976, "Resource Conservation and Recovery Act (Solid Waste Disposal Act)," United States Code, October 21, 1976.

42 USC § 7401 et seq., 1970, “Clean Air Act,” United States Code, December 31, 1970 (as amended).

42 USC $\S 9601$ et seq., 1980, “Comprehensive Environmental Response, Compensation and Liability Act of 1980 (CERCLA/Superfund)," United States Code, December 11, 1980.

42 USC § 9621, 1998, “Cleanup Standards,” United States Code, January 26, 1998.

DEQ, 2000, B. R. Monson, DEQ, to D. N. Rasch, DOE-ID, Enclosure: “Consent Order," Idaho Code § 39-4413, June 14, 2000.

DOE O 435.1, 2001, "Radioactive Waste Management," Change 1, U.S. Department of Energy, August 28, 2001.

DOE O 5400.5, 1993, "Radiation Protection of the Public and the Environment," Change 2, U.S. Department of Energy, January 7, 1993.

DOE and EPA, 1995, Policy on Decommissioning of Department of Energy Facilities Under the Comprehensive Environmental Response, Compensation, and Liability Act (CERCLA), KLF-211-95, Rev. 0, U.S. Department of Energy, Washington, D.C., and U.S. Environmental Protection Agency, Washington, D.C., May 22, 1995.

DOE-ID, 1991, Federal Facility Agreement and Consent Order for the Idaho National Engineering Laboratory, Administrative Docket No. 1088-06-120, U.S. Department of Energy Idaho Operations Office; U.S. Environmental Protection Agency, Region 10; Idaho Department of Health and Welfare, December 9, 1991.

DOE-ID, 1992, Record of Decision, Test Reactor Area Perched Water System, Operable Unit 2-12, Idaho National Engineering and Environmental Laboratory, Idaho Falls, Idaho, Document ID 5230, Rev. 0, U.S. Department of Energy Idaho Operations Office; U.S. Environmental Protection Agency, Region 10; Idaho Department of Health and Welfare, December 1992.

DOE-ID, 1994, Track 2 Sites: Guidance for Assessing Low Probability Hazard Sites at the INEL, DOE/ID-10389, Rev. 6, U.S. Department of Energy Idaho Operations Office, January 1994.

DOE-ID, 1997, Final Record of Decision Test Reactor Area Operable Unit 2-13, Idaho National Engineering and Environmental Laboratory, Idaho Falls, Idaho, DOE/ID-10586, U.S. Environmental Protection Agency, Idaho Department of Environmental Quality, U.S. Department of Energy Idaho Operations Office, December 1997. 
DOE-ID, 2000, Explanation of Significant Differences to the Record of Decision for Test Reactor Area Operable Unit 2-13, DOE/ID-10744, Rev. 0, U.S. Environmental Protection Agency, Idaho Department of Environmental Quality, U.S. Department of Energy Idaho Operations Office, May 2000.

DOE-ID, 2003, Performance Assessment for the INEEL CERCLA Disposal Facility Landfill, DOE/ID-10978, Rev. 0, U.S. Department of Energy Idaho Operations Office, August 2003.

DOE-ID, 2004a, Groundwater Monitoring Plan for the Test Reactor Area Operable Unit 2-13, DOE/ID-10626, Rev. 5, U.S. Department of Energy Idaho Operations Office, September 2004.

DOE-ID, 2004b, Idaho National Engineering and Environmental Laboratory Cultural Resource Management Plan, DOE/ID-10997, Rev. 0, U.S. Department of Energy Idaho Operations Office, August 2004.

DOE-ID, 2005, ICDF Complex Waste Acceptance Criteria, DOE/ID-10881, Rev. 2, U.S. Department of Energy Idaho Operations Office, July 2005.

DOE-ID, 2006a, Engineering Evaluation/Cost Analysis for Decommissioning of the Engineering Test Reactor Complex, DOE/ID-11272, Rev 0, October 2006.

DOE-ID, 2006b, ICDF Waste Acceptance Criteria, DOE/ID-10881, Rev 3 U.S. Department of Energy Idaho Operations Office, October 2006.

EDF-5142, 2006, "Groundwater Pathway Risk Assessment for the Engineering Test Reactor Complex Closure,” Rev. 2, Idaho National Laboratory, Idaho Cleanup Project, October 2006.

EDF-6133, 2006, "ETR Reactor Vessel Source Term and External Dose Rates," Rev. 2, Idaho National Laboratory, Idaho Cleanup Project, September 2006.

EDF-6138, 2006, "Radiological Characterization of the ETR Complex External Surfaces," Rev. 2, Idaho National Laboratory, Idaho Cleanup Project, September 2006.

EDF-6225, 2006, "Engineering Test Reactor Complex Chemical Constituent Source Term,” Rev. 1, Idaho National Laboratory, Idaho Cleanup Project, January 2006.

EDF-6291, 2006, "Radiological Characterization of the Engineering Test Reactor (ETR) Complex Internal Surfaces,” Rev. 1, Idaho National Laboratory, Idaho Cleanup Project, September 2006.

EDF-6304, 2005, “ETR Complex Activity vs. Depth,” Rev. 0, Idaho National Laboratory, Idaho Cleanup Project, November 2005.

EDF-6705, 2006, "Screening-Level Ecological Risk Assessment of the Engineering Test Reactor and Materials Testing Reactor Removal Alternatives," Rev. 0, Idaho National Laboratory, Idaho Cleanup Project, April 2006.

EDF-6958, 2006, “Engineering Test Reactor Radionuclides and Radionuclide Relative Ratios,” Rev. 1, Idaho National Laboratory, Idaho Cleanup Project, September 2006.

EDF-7222, 2006, "ETR Beryllium Reflector and Vessel Transuranic Inventories,” Rev. 0, Idaho National Laboratory, Idaho Cleanup Project, October 2006. 
EDF-7243, 2006, "Streamlined Risk Assessment for the D\&D of the ETR Reactor Facilities," Rev. 0, Idaho National Laboratory, Idaho Cleanup Project, October 2006.

EPA, 1993, Guidance on Conducting Non-Time Critical Removal Actions Under CERCLA, EPA/540-R-93-057, U.S. Environmental Protection Agency, August 1993.

EPA, 1996, Soil Screening Guidance: User's Guide, Second Edition, EPA/540/R-96/018, U.S. Environmental Protection Agency, July 1996.

EPA, 2000a, Soil Screening Guidance for Radionuclides: User's Guide, EPA/540-R-00-007, U.S. Environmental Protection Agency, October 2000.

EPA, 2000b, A Guide to Developing and Documenting Cost Estimates During the Feasibility Study, EPA/540-R-00-002, U.S. Environmental Protection Agency, July 2000.

EPA, 2006, Region 10 Final Policy on the Use of Institutional Controls at Federal Facilities, U.S. Environmental Protection Agency, May 2006.

Idaho Code § 39-4401 et seq., 1983, "Hazardous Waste Management Act of 1983," State of Idaho, Boise, Idaho.

IDAPA 58.01.01.161, 1995, "Toxic Substances," Idaho Administrative Procedures Act, Idaho Department of Environmental Quality, June 30, 1995.

IDAPA 58.01.01.650, 1994, "Rules for Control of Fugitive Dust," Idaho Administrative Procedures Act, Idaho Department of Environmental Quality, May 1, 1994.

IDAPA 58.01.01.651, 1994, “General Rules,” Idaho Administrative Procedures Act, Idaho Department of Environmental Quality, May 1, 1994.

IDAPA 58.01.05.006, 2006, "Standards Applicable to Generators of Hazardous Waste," Idaho Administrative Procedures Act, Idaho Department of Environmental Quality, April 11, 2006.

IDAPA 58.01.05.008, 2006, "Standards for Owners and Operators of Hazardous Waste Treatment, Storage, and Disposal Facilities," Idaho Administrative Procedures Act, Idaho Department of Environmental Quality, April 11, 2006.

IDAPA 58.01.05.011, 2006, “Land Disposal Restrictions," Idaho Administrative Procedures Act, Idaho Department of Environmental Quality, April 11, 2006.

IDAPA 58.01.05.016, 2006, “Standards for Universal Waste Management," Idaho Administrative Procedures Act, Idaho Department of Environmental Quality, April 11, 2006.

IDAPA 58.01.06.012, 2003, “Applicable Requirements for Tier II Facilities," Idaho Administrative Procedures Act, Idaho Department of Environmental Quality, April 3, 2003.

IDAPA 58.01.011, 1997, “Ground Water Quality Rule," Idaho Administrative Procedures Act, Idaho Department of Environmental Quality, March 20, 1997.

NCRP, 1996, Screening Models for Releases of Radionuclides to Atmosphere, Surface Water, and Ground-Water, NCRP Report No. 123, National Council on Radiation Protection. 
Public Law 99-499, 1986, "Superfund Amendments and Reauthorization Act of 1986 (SARA)," 100 Statutes 1728, Public Law, October 17, 1986.

Rood, A. S., 2003, GWSCREEN: A Semi-Analytical Model for Assessment of the Groundwater Pathway from Surface or Buried Contamination: Theory and User's Manual Version 2.5, INEEL/EXT-98-00750, Rev. 1b, Idaho National Engineering and Environmental Laboratory April 2003. 


\section{Appendix A}

Public Comments Received during the Comment Period and Responses to Comments 


\section{Appendix A}

\section{Public Comments Received during the Comment Period and Responses to Comments}

The public participation period for the Engineering Evaluation/Cost Analysis for Decommissioning the ETR Complex (EE/CA) (DOE-ID 2006) was from October 28, 2006 through November 26, 2006. A public notice was sent to nine different Idaho and Wyoming newspapers on October 28, 2006. The notice was posted in the U.S. Department of Energy (DOE) Administrative Record electronically, and hard copies of the document were sent to the DOE Public Reading rooms in Idaho Falls and Boise. A presentation was provided to the Idaho National Laboratory (INL) Citizens Advisory Board on November 13, 2006 and discussions were held on November 14, 2006, which were also open to participation from the general public. A number of individuals and groups provided comments.

Written comments on the EE/CA have been received from:

Shoshone-Bannock Tribes, Fort Hall

Coalition 21, Idaho Falls

Mr. Glen Brisco, Idaho Falls

Anonymous Commenter

INL Citizens Advisory Board

The Partnership for Science and Technology, Idaho Falls

Environmental Defense Institute, Troy, Idaho

Comments received were compiled and comments that are similar in meaning are summarized and consolidated below. A complete list of public and Tribe comments are presented in Appendix B along with the resolution references to the comment responses below.

Comment \#1: Received comments stating that there may be "hot-spots" of radionuclides that exceed the Waste Acceptance Criteria (WAC) for the INEEL CERCLA Disposal Facility (ICDF) or that the concentrations of nuclides were not properly calculated.

Response \#1: Consistent with the CERCLA process, compliance to applicable, relevant, and appropriate requirements must be considered for activities being performed, including waste handling and disposal. Many factors were considered to determine the applicability and acceptability of the ETR vessel disposal at the ICDF including an evaluation in accordance with the radionuclide classification system in 10 CFR 61.55 and corresponding classification of radioactive wastes under DOE Order 435.1 to develop and recommend a preferred alternative in the $\mathrm{EE} / \mathrm{CA}$.

Waste characterization and classification included retrieving a sample of the beryllium reflector for analysis and direct radiological readings of the activated internals. Also evaluated were the appropriateness of the ETR vessel as the waste package and the feasibility of removing parts of the vessel internals. The appropriate waste package was determined to be the vessel with the internals in place. Internals, including the beryllium, were designed to be removed when the ETR facility was in operating mode. The facilities, 
procedures, safety basis documentation, and qualified people were in place to remove and handle the beryllium reflector and other internals. The vessel was filled with water to provide shielding to protect the worker. The canal and reactor transfer system was operational to allow vessel components to be transferred in such a way that they were never unshielded by water. Under the current status of the facility, none of the previously listed conditions exist. Additionally, the beryllium reflector has become "swollen" due to the effects of the neutron flux it experienced during operations. The expansion of the beryllium has wedged portions of the reflector into the surrounding vessel components. Therefore, the beryllium can no longer be removed under the current conditions and in accordance with accepted operational practices. Based on these evaluations, disposal of the ETR vessel as a waste package at the ICDF was in compliance with the WAC and was determined to be the best alternative to protect the worker, as well as the least costly alternative.

Comment \#2: Received comments stating that Alternative 2 might be a better choice because it allows the vessel to remain in place and therefore would prevent unnecessary worker exposure.

Response \#2: Alternative 2, grouting the vessel in place with a concrete monolith constructed over the above ground portions of the vessel, does indeed pose less short-term risk for radiological exposure and industrial hazards to workers than Alternative 3, the recommended alternative, as the vessel would remain below ground level. However, Alt 2 does not satisfy the DOE mission to address the disposition of "excess" (no further mission) radiologically contaminated facilities, by reducing their current or future risk footprint to potential animal or human receptors as the facility degrades over time. Workers will be trained to perform the tasks safely, and mock-up situations will be used to gain proficiency. Adequate radiological and industrial safety controls are in place to protect workers. Additionally, the work force and management that will perform vessel removal have been selected for their previous experience and success doing similar work.

Comment \#3: Received comments questioning the methods used to determine the transuranic concentrations of the ETR vessel and the appropriateness of averaging the transuranic concentration of the beryllium reflector over the entire waste package.

Response \#3: The total transuranic content in the entire vessel is approximately .148 curies or about .001 ounce. When this is averaged over the weight of the ungrouted waste package (vessel plus internals), the transuranic concentration is less than 2 billionth of a curie per gram weight $(1.99 \mathrm{nCi} / \mathrm{gr})$. Further discussion of the appropriateness of considering the ETR vessel, with the internals in place, as the waste package is provided in the response to Comment \#1 above.

Comment \#4: Received a comment questioning the assumption that seemed to state that corrosion products, such as from chromium, would migrate horizontally rather than downward.

Response \#4: The assumption was made to clarify that, to be conservative, the model only considered downward movement in contaminants and did not factor in horizontal movement. If horizontal migration were to be included, attenuation of the corrosion products in the vadose zones would further reduce the concentrations reaching the aquifer.

Comment \#5: Received comments expressing a concern for the consistency of closures and end states for the INL. One comment also stated that DOE's action does not seem to be consistent with actions at Pit 4 and Pit 9 waste cleanup at the INL or the closure of the old Waste Calcine Facility (WCF) at INTEC. 
Response \#5: Facility end states are evaluated individually through several regulatory pathways including the National Environmental Policy Act (NEPA); the Comprehensive Environmental Response, Compensation and Liability Act (CERCLA) remedial investigation/feasibility study; the EE/CA; or the Resource Conservation and Recovery Act Closure process. This provides opportunities for Stakeholder input. Though the physical end states may appear to not be consistent, this evaluation process ensures that they are all protective of human health and the environment.

The radionuclides at the ETR Complex that are of concern for exposure are gamma and beta emitters; therefore, the hazard is direct exposure. The wastes from Rocky Flats that are being cleaned up at Pit 4 and Pit 9 are mostly alpha emitters so the hazard is uptake by the receptor. Different hazards required different remediation strategies to protect the worker.

There are similarities between Alternative 2 (ETR vessel entombment) and the 1999 entombment of WCF at INTEC; however entombment of the ETR vessel in place does not satisfy the current DOE mission to address the disposition of "excess" (no further mission) radiologically contaminated facilities, by reducing their current or future risk footprint to potential animal or human receptors as the facility degrades over time. The ICDF became operational in 2002 to allow CERCLA wastes from environmental restoration and decommissioning and demolition activities to be consolidated.

Comment \#6: Received comments questioning why it is appropriate to dispose of the ETR vessel at ICDF instead of leaving it in place at RTC, and whether a carcinogenic risk will remain at ICDF or at the ETR area, and what risks would be imposed on future residents located near these sites.

Response \#6: As prescribed in the OU 2-13 ROD, very conservative future land use assumptions were used to develop the risk analysis for the ETR Complex. The results of the risk assessment indicate an unacceptable risk would exist for this hypothetical future resident. Therefore, Alternative 2 does not meet the CERCLA threshold criteria of protecting human health and the environment, and thus this alternative is not recommended as an appropriate response action.

Placement of the ETR vessel at the ICDF is more appropriate than leaving the ETR vessel in place at the RTC under Alternative 2. The ICDF uses less conservative assumptions for establishing the future land use, as described in the OU 3-13 ROD, than is prescribed in the OU 2-13 ROD. The risk assessment for the ICDF assumes that land use controls will prohibit future residential use indefinitely, so there was no evaluation of risks to a hypothetical future resident. Both potential risks to industrial workers and impacts to the aquifer were evaluated for the ICDF and found to be acceptable. Additionally, with the reactor vessel removed as proposed under Alternative 3, risks to a future hypothetical resident at the RTC were determined to be acceptable, using the exposure assumptions described in the preceding section. Therefore, Alternative 3 meets the threshold criteria of protecting human health and the environment and is an appropriate response action.

Note: The actual calculated excess cancer risk for Alternative 2 was 1.546 people in 10,000 , which was rounded to 2 people to ensure conservatism is maintained throughout the process. 
Comment \#7: Some commenters stated a concern that putting the ETR vessel in the ICDF would set a precedent for placing other reactor vessels in the ICDF or even allowing waste from other non-INL sites to dispose at ICDF.

Response \#7: To dispose at the ICDF, waste, including reactor vessels, must be evaluated under the CERCLA process; proposed actions must receive EPA and State of Idaho approval; and the public and the Tribe must have an opportunity to provide input. Each reactor vessel will be evaluated through this regulatory process separately to determine the alternative that is most protective of human health and the environment while being consistent with the DOE mission of risk footprint reduction and waste consolidation.

All CERCLA wastes generated from an INL Federal Facility Agreement and Consent Order (FFA/CO) ROD or NTCRA action are evaluated for compliance with current disposal site waste acceptance criteria and, accordingly, disposed at the ICDF, TAN, or CFA demolition landfills; disposed at off-Site facilities; or stored pending final disposition. In this respect, the ICDF, unless prohibited, is the intended disposal site for current and future CERCLA wastes.

The Final Record of Decision for Idaho Nuclear Technology and Engineering Center, Operable Unit 3-13 prohibits disposal of non-INL waste in the ICDF.

Comment \#8: Received comments that expressed a concern that disposal of low-level waste at the ICDF may not be the best practice based on problems with past disposal practices.

Response \#8: Past disposal practices at the INL did not incorporate the controls that are required for disposal at the ICDF. Lessons learned from disposal at the RWMC and other disposal sites across the DOE Complex and commercial disposal sites across the country were incorporated into the design and operation of the ICDF. Some of the ICDF controls include:

- $\quad$ The leachate from disposed waste at the ICDF is managed using a double geotextile liner for collection

- $\quad$ The ICDF has a lower most layer of compact clay to protect groundwater by capturing and holding contaminants to prevent migration if the geotextile liners should fail in the future

- $\quad$ The ICDF WAC was established based on conservative groundwater modeling and compatibility analysis

- $\quad$ The ICDF is located out of the 100-year floodplain

- Operational controls are in place to minimize voids spaces and prohibit free liquids in the waste

- Wastes are treated as necessary to stabilize prior to disposal

- A groundwater monitoring system, which includes perched as well as aquifer wells, provides early detection of releases

- A waste placement tracking system records the location of the waste in the disposal cell if future retrieval becomes necessary 
- An engineered cover to minimize infiltration of precipitation into the wastes will eventually be added

- Access controls, monitoring, and maintenance will remain in place for as long as the contents of the ICDF remain a threat to human health or the environment if uncontrolled.

Comment \#9: Received several comments questioning why separate radionuclides were evaluated for the groundwater risk and the soil pathway risk.

Response \#9: The lists of primary contaminants of concern are different between exposure pathways largely because some radionuclides tend to bind up in site soils whereas others are more mobile and prone to migration through the soil column.

Comment \#10: Received comments stating that the continuing surveillance and maintenance costs for leaving the vessel in place under Alternative 2 did not seem to address the true or life cycle costs of that Alternative.

Response \#10: We agree with the commenters that one year of surveillance and maintenance does not fully represent the ultimate cost for implementing Alternative 2 and that if the vessel were grouted in place, the life cycle costs of implementation would likely exceed the costs of the recommended alternative (Alternative 3).

Comment \#11: Several commenters wanted clarification regarding what cleanup work is being done under deactivation and what is being done under the non-time-critical removal action (NTCRA) regarding what is being left in place.

Response \#11: Deactivation activities remove much, if not all, the Resource Conservation and Recovery Act (RCRA) hazardous, Toxic Substance and Control Act (TSCA), and asbestos-containing materials, and reduce as much of the radioactive source term as possible. These activities were ongoing during the ETR Complex EE/CA process.

As stated in Section 1.1 of the EE/CA, the scope of the EE/CA was to 1) determine the final end state of the ETR reactor building, 2) determine the final disposition of the ETR vessel, and 3 ) evaluate risks to human health and the environment at the end of all deactivation and decommissioning activities. In addition, the EE/CA states that of the approximately 59,000 total Curies currently present in the ETR Complex, if the vessel is removed, approximately one-tenth (0.1) of a Curie would remain in buildings and structures throughout the complex at the proposed end state of the recommended alternative (Alternative 3).

Comment \#12: Received comments questioning why the NTCRA removal action will actually be more efficient or provide better protection of the environment and human health.

Response \#12: Under the U.S. Department of Energy (DOE) and U.S. Environmental Protection Agency (EPA) Policy on Decommissioning of Department of Energy Facilities Under the Comprehensive Environmental Response, Compensation and Liability Act (DOE and EPA 1995), a NTCRA may be taken when DOE determines that the action will prevent, minimize, stabilize, or eliminate a risk to health and/or the environment. When DOE determines that a NTCRA is necessary, DOE is authorized to evaluate, select, and implement the removal action that DOE determines is most appropriate to address potential risks posed by the release or threat of release. 
As stated in the ETR EE/CA (Section 3), the selected alternative for the ETR NTCRA will be consistent with the remedial action objectives established in the OU 2-13 remedial investigation/feasibility study (RI/FS) and documented in the OU 2-13 ROD. The NTCRA is more efficient in that it achieves the ROD requirements in the timeliest manner with reasonable costs. In addition, performing decommissioning and demolition (D\&D) now, while the facility is intact, allows for controlled demolition and thus management of potential radiological releases and exposures versus performing this task on a more unstable structure in the future.

Comment \#13: One commenter expressed a concern regarding the weight of the vessel after the internals and the containment bathtub have been grouted, and the effect this weight will have on the liner over a long period of time.

Response \#13: An analysis has been performed to determine the effect of the weight of the vessel, including internal grout and grout in the containment bathtub, on the liner system. The vessel will be placed at least $8 \mathrm{ft}$ above the operations layer (12 feet above the geocomposite clay liner) to spread the weight over a large area. By doing this the pressure on the liner will be well within the design parameters of the disposal cell. Please note that the weight of the grout being used is about the same as the weight of soil, so the grout does not add weight to the liner beyond that of soil.

Comment \#14: One commenter stated: “....the soil pathway analysis does not address the possibility that radionuclides may exceed the Regulatory Commission (NRC) definition of Transuranic waste (greater $100 \mathrm{nCi} / \mathrm{g}$ ), which would require transport to WIPP."

Response \#14: The purpose of the soil pathway analysis was to determine risk to a future resident. This assessment is done in compliance with EPA requirements and guidance. The determination of transuranic waste is not part of the risk assessment but is discussed in Section 2.3.1.1 of the EE/CA. As discussed in the response to Comment \#3 above, the vessel is well below the definition of transuranic waste.

Comment \#15: One commenter was concerned about the completeness of characterization and the accuracy of the models used to determine the radioactive materials remaining after D\&D at the ETR Complex in the form of contaminated soils and debris and the resulting risk to the workers and public.

Response \#15: The ETR, like the Materials Test Reactor, was built and operated to develop an understanding of the effects of radiation on materials. Many hundreds of tests were run and the results were studied until a complete understanding of the effects and byproducts of nuclear fission and neutron fluxes was achieved. This information has been well documented and forms the basis of the characterization and modeling efforts used in the ETR EE/CA. The modeling has been refined over the years to be increasingly accurate, however still conservative overall. Models used included the Origin II Code and the MCNP4C Codes. Continued characterization has been conducted throughout the D\&D work to validate the modeling and to ensure established cleanup levels for soils and debris are achieved upon completion of the project. Characterization included sampling residues in piping and performing direct radiological surveys of walls and piping, as well as inside and outside of the reactor vessel. Radiological dose rates of hard-to-reach areas on the outside of the reactor vessel were obtained using thermoluminescent dosimetry chips that were fed up along the vessel walls. 
Comment \#16: Received comments supporting the selected alternative stating that it was the best balance of public and worker safety with cost.

Response \#16: We agree with the comment.

Comment \#17: One commenter stated that future costs should be in present value of money and the number of years should be indicated as should the discount/interest rate used. The commenter also stated that the estimate of future costs should stop at 20 years because requirements beyond 20 years are uncertain and present net worth beyond 20 years to infinity is close to zero.

Response \#17: The net present value method was used for reporting the costs of each of the alternatives in accordance with 40 CFR 300.430 (e)(9)(G)(3), "The National Contingency Plan" and Guidance on Conducting Non-Time-Critical Removal Actions Under CERCLA (EPA 1993). The costs for surveillance and maintenance for the No Action Alternative was calculated to the year 2095 to be consistent with the OU 2-13 ROD.

Comment \#18: One commenter stated that DOE should demonstrate their capability and technologies to cleanup and restore soils and the vessel at the ETR.

Response \#18: The activities being conducted at the ETR Complex are resulting in an estimated $99.99 \%$ reduction of contamination at the site. The cleanup subcontractor is removing components and piping to eliminate contamination that could be released into the soils at ETR in the future. Risk assessments indicate that if the ETR vessel is removed there will be no unacceptable future risk to a receptor (human or ecological) at this site.

Comment \#19: One commenter stated that the available information leads one to believe that DOE has not performed adequate risk assessments.

Response \#19: DOE and the cleanup subcontractor disagree with the comment. Extensive characterization activities have been conducted starting in 1982 when the ETR Complex was first inactivated and recently with surveys and sampling. Information that was not available was estimated using very conservative assumptions and modeling methodologies. The ETR $\mathrm{EE} / \mathrm{CA}$ followed the required information-gathering guidance and the data presented fully supported the decision-making process.

Comment \#20: Several commenters requested clarification of the waste and materials that would be left in place under Alternative 2 and Alternative 3.

Response \#20: Removal of material proposed under the decommissioning of the ETR Complex would achieve a significant reduction in the amount of waste remaining in the RTC area. Removal of the ETR Complex buildings' and structures' superstructure and the ETR vessel would reduce the total curies currently present in the ETR Complex from over 59,000 $\mathrm{Ci}$ to an estimated $.06 \mathrm{Ci}$ primarily located on building and structure surfaces as fixed or lose contamination. The reactor building would be demolished to ground surface under both Alternative 2 and Alternative 3; structures and systems below ground surface consisting of inert materials such as piping, tanks, structural metal, and utility systems, would be abandoned in place.

Comment \#21: One commenter stated that disposing of the ETR vessel at the ICDF appears to be a contradiction to the spirit, if not the letter, of the Batt Agreement and the WIPP transportation agreements. 
Response \#21: The Batt agreement deals with high-level waste, spent nuclear fuel, and transuranic waste; the ETR vessel is neither of these types of waste. The ETR vessel is low level waste and its disposal is in compliance with the ICDF WAC. The ICDF was established in the OU 3-13 ROD which received public and Tribal review and had comment. The Batt agreement also encourages the use of CERCLA risk-based cleanups such as the ETR NTCRA by endorsing the completion of the cleanup activities at the INL under the FFA/CO.

Since the ETR vessel is not TRU waste, the WIPP transportation agreements would not apply.

Comment \#22: One commenter stated there was doubt in the quality and quantity of wastes subject to cleanup. The commenter also stated that the Shoshone Bannock Tribes should be allowed a specific assessment of the waste inventories scheduled for deactivation and this new removal plan (ETR NTCRA). The commenter also stated that the Tribes should have been consulted on DOE's development of the Remedial Action Objectives (RAOs) at the ETR.

Response \#22: DOE Idaho, pursuant to the "DOE American Indian and Alaska Natives Tribal Government Policy" dated January 20, 2006, solicited the Tribes' comments on the Engineering Evaluation/Cost Analysis for Decommissioning of the Engineering Test Reactor Complex, DOE/ID-11272 (EE/CA). In addition to the EE/CA, DOE held briefings on this project and made formal presentations to the INL Citizens Advisory Board (CAB). The Tribes have a DOE tribal liaison who is also a member of the CAB. The ETR EE/CA provided a description of past cleanup activities at the ETR Complex and the estimates of quantities of contamination that were being addressed under deactivation and the NTCRA.

As stated in the ETR EE/CA, the NTCRA is subject to the RAOs that were established in the Final Record of Decision, Test Reactor Area Operable Unit 2-13, DOE/ID-10586, December 1997. This ROD and the RAOs contained within were developed under the 1991 FFA/CO. Although the Tribes are not a signatory on the FFA/CO, under the CERCLA process, the Tribes' input is solicited through public notice, meetings, and the opportunity to comment on remedy selection. All final cleanup decisions are reached only after evaluating, through public notice and comments (including Tribal comments), the feasibility and safety of a full range of alternatives. Under the FFA/CO, selection of final cleanup remedies for Operable Unit 2-13 and other CERCLA sites is the joint responsibility of DOE, EPA, and the State of Idaho.

Comment \#23: One commenter stated that the land should be restored back to its original state without restrictions that deny access to the Shoshone Bannock Tribes.

Response \#23: The ETR Complex, which is the subject of this NTCRA, has occupied this specific location for decades. It has long since become unsuitable for hunting activities because of existing fencing and industrial activity and infrastructure. The conservative nature of the OU 2-13 risk assessment bounds the range of activities such as hunting, gathering, and collecting that would result in Tribal members' exposure to contamination if this location were unoccupied lands. The selected alternative would be fully protective for these activities, and certainly the risk to Tribal members doing these activities would be significantly less than the risk to workers conducting excavation or similar activities to retrieve the estimated $.1 \mathrm{Ci}$ of radioactive contamination remaining at the ETR complex site at the completion of the selected alternative. 
Appendix B

\section{Public and Tribe Comment Resolution Matrix}




\section{Appendix B}

\section{Public and Tribe Comment Resolution Matrix}

\begin{tabular}{|c|c|c|c|}
\hline \# & Submitted by & Comment & $\begin{array}{l}\text { Appendix A } \\
\text { Response } \\
\text { References }\end{array}$ \\
\hline 1 & $\begin{array}{l}\text { Shoshone Bannock } \\
\text { Tribes }\end{array}$ & $\begin{array}{l}\text { Costs and Safety: } \\
\text { There is a concern after a review of the EE/CA document. It seems to lack in some areas as to } \\
\text { what the cost associated for each alternative and safety concerns of the work force. The } \\
\text { removal of the reactor vessel may allow workers to receive high dose rates of radiation. The } \\
\text { alternative } 2 \text { of leaving in place and grouting seems safer for current and future exposure to } \\
\text { workers. }\end{array}$ & $\# 2, \# 6, \# 10$ \\
\hline 2 & $\begin{array}{l}\text { Shoshone Bannock } \\
\text { Tribes }\end{array}$ & $\begin{array}{l}\text { The INL has various areas that have been D\&D'd at this time, but the consistency of how it is } \\
\text { done is a concern for us. For example the Waste Calciner was grouted in place and now has a } \\
\text { concrete monolith above ground, The INTEC tank farm will have a cap for prevention of water } \\
\text { recharge. We know that if the reactor vessel were to be cut up and removed from the state it } \\
\text { would generate high radiation exposure rates for the workers. If it were to be left in place and } \\
\text { grouted then it would similar to the WCF at the INTEC facility. }\end{array}$ & $\# 5$ \\
\hline 3 & $\begin{array}{l}\text { Shoshone Bannock } \\
\text { Tribes }\end{array}$ & $\begin{array}{l}\text { The reference to alternative } 2 \text { regarding the public health protectiveness of the concrete } \\
\text { containment and institutional controls regarding the issue of Nb-94 raises some questions. The } \\
\text { document states that Nb-94 located in the internals of the reactor vessel and left in the } \\
\text { containment building may create a carcinogenic risk for future residents. If the vessel were to } \\
\text { placed in the ICDF wouldn't there still be a carcinogenic risk in that area? } \\
\text { It seems that ICDF is considered a safer place. We would like an explanation of the } \\
\text { carcinogenic risk that this poses for a future resident that may decide to live in this ETR area } \\
\text { compared to the risk to a future residents who may choose to reside near the ICDF. }\end{array}$ & $\# 6$ \\
\hline 4 & $\begin{array}{l}\text { Shoshone Bannock } \\
\text { Tribes }\end{array}$ & $\begin{array}{l}\text { Our concern is if the reactor vessel is to be removed and placed in the ICDF, then ICDF may } \\
\text { be designated as a waste dump site for everything on the INL By reducing the footprint, it } \\
\text { seems that we will have put in place another high-level waste storage site. If the ETR vessel } \\
\text { was left in the containment and grouted in place there would only be one area of concern. }\end{array}$ & $\# 5, \# 7$ \\
\hline
\end{tabular}




\begin{tabular}{|c|c|c|c|}
\hline \# & Submitted by & Comment & $\begin{array}{l}\text { Appendix A } \\
\text { Response } \\
\text { References }\end{array}$ \\
\hline & & $\begin{array}{l}\text { There was a scenario mentioned that discussed the type of standards the INL will be in a 100- } \\
\text { year time period, those areas that will have institutional controls will never be able meet } \\
\text { residential standards. Further more, there is concern that once that ICDF is designated for the } \\
\text { ETR vessel, then it will set precedence for all waste (reactors) to be placed there. Finally, there } \\
\text { is concern that if the ICDF is designated for this type of waste there may be a remote } \\
\text { possibility that other Environmental Management cleanup sites may look to the INL as a } \\
\text { disposal area. }\end{array}$ & \\
\hline 5 & $\begin{array}{l}\text { Shoshone Bannock } \\
\text { Tribes }\end{array}$ & $\begin{array}{l}\text { One other issue is the weight that this vessel after the grouting of the internals and the } \\
\text { containment bathtub will have on the liner over a long period of time. If this alternative is } \\
\text { decided upon then in the future the other two reactors may also qualify for disposal in this area } \\
\text { that may add additional weight to the liners. }\end{array}$ & $\# 13$ \\
\hline 6 & $\begin{array}{l}\text { Shoshone Bannock } \\
\text { Tribes }\end{array}$ & $\begin{array}{l}\text { Is this consistent with the Idaho Cleanup Project vision that has been designated as a low level } \\
\text { waste area? Low level waste and debris is what we understood would be deposited in this area. } \\
\text { In the current method of cleanup we have a concern when various types of "low Level Waste" } \\
\text { has been deposited in this ICDF facility we may have generated a legacy of future waste that } \\
\text { may have to be removed. In the past they deemed that placing radioactive waste in the unlined } \\
\text { pits and trenches was the best practice at that time and now we know what the consequences } \\
\text { are. }\end{array}$ & $\# 5, \# 8$ \\
\hline 7 & $\begin{array}{l}\text { Shoshone Bannock } \\
\text { Tribes }\end{array}$ & $\begin{array}{l}\text { Summary } \\
\text { In summary the Tribes would like to have all of the radioactive waste removed from the INL } \\
\text { and Idaho. We understand that safety of the workers and of the safety of the transportation of } \\
\text { this ETR material will be unlikely. We also understand the issue of reducing the INL footprint } \\
\text { that is a concern to DOE in reaching their milestones. But we feel that alternative } 2 \text { would } \\
\text { reduce the exposure to the workers of it was grouted in place and if a concrete cap was placed } \\
\text { above the building such as the WCF at INTEC. } \\
\text { Institutional control will dictate when and where a resident may chose to live but we see that if } \\
\text { the reactor vessel was placed in the ICDF it will be monitored for more extensively and for a } \\
\text { longer period of time thus increasing costs. }\end{array}$ & $\# 2, \# 6$ \\
\hline
\end{tabular}




\begin{tabular}{|c|c|c|c|}
\hline \# & Submitted by & Comment & $\begin{array}{l}\text { Appendix A } \\
\text { Response } \\
\text { References }\end{array}$ \\
\hline 8 & $\begin{array}{l}\text { Shoshone Bannock } \\
\text { Tribes } \\
\text { Roger Turner }\end{array}$ & $\begin{array}{l}\text { The Tribes are an affected tribe with respect to DOE EM/Clean-up plans and activities, and } \\
\text { have a role in DOE's planning and implementation process for environmental restoration and } \\
\text { waste management. DOE should work closely with the Tribes on a government-to-government } \\
\text { basis, as outlined in U.S. DOE's Tribal Policy, and DOE Order 1230.2, Which provides that } \\
\text { DOE will: } \\
\text { "implement a proactive outreach effort of notice and consultation regarding current and } \\
\text { proposed actions affecting tribes. This effort will include timely notice to all potentially } \\
\text { impacted Indian nations in the early planning stages of the decision-making process, } \\
\text { including pre-draft consultation, in the matter of regulatory policies on matters that } \\
\text { significantly or uniquely affect their communities." } \\
\text { "In carrying out this relationship with the Tribes, the DOE will assess the impact of } \\
\text { DOE's plans, projects, programs, activities on tribal trust resources and assure that tribal } \\
\text { government rights and concerns are considered during the development of such plans, } \\
\text { projects, programs, and activities." } \\
\text { The Shoshone-Bannock Tribes (Tribes) believe that this includes the clean-up at the ETR. }\end{array}$ & $\# 12$ \\
\hline 9 & $\begin{array}{l}\text { Shoshone Bannock } \\
\text { Tribes } \\
\text { Roger Turner }\end{array}$ & $\begin{array}{l}\text { Inadequate presentation of the on-going Deactivation activities compared to the proposed } \\
\text { NTCRA activities - The DOE, in this NTCRA, states that (page 1-2) :"Deactivation activities } \\
\text { that were begun in } 1981 \text { and are continuing in advance of the NTCRA Action Memorandum } \\
\text { are not included in the scope of the NTCRA." This isn't an adequate explanation; Section } 2.2 \\
\text { needs to explain in plain language what activities are continuing through Deactivation and } \\
\text { other parts of OU-2-13. The Tribes need to know not only what isto be cleaned up under } \\
\text { "Deactivation" activities but also why some of it is proposed under NTCRA. }\end{array}$ & $\# 11, \# 12$ \\
\hline 10 & $\begin{array}{l}\text { Shoshone Bannock } \\
\text { Tribes } \\
\text { Roger Turner }\end{array}$ & $\begin{array}{l}\text { As drafted the NTCRA only explains that DOE has the authority to initiate a NTCRA...not } \\
\text { why the removal action will actually be more efficient or provide better protection of the } \\
\text { environment and human health. }\end{array}$ & $\# 12$ \\
\hline
\end{tabular}




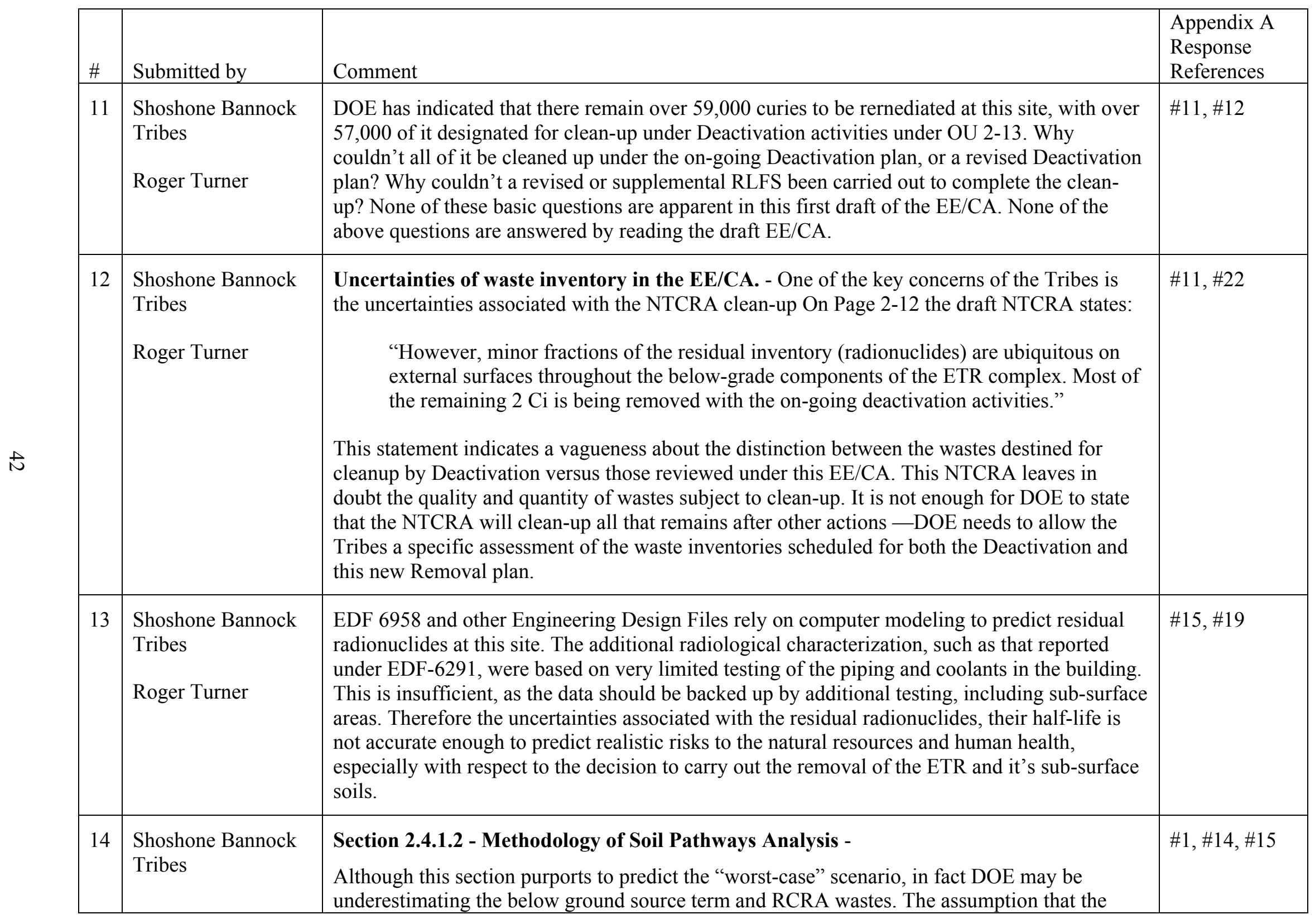




\begin{tabular}{|c|c|c|c|}
\hline \# & Submitted by & Comment & $\begin{array}{l}\text { Appendix A } \\
\text { Response } \\
\text { References }\end{array}$ \\
\hline & Roger Turner & $\begin{array}{l}\text { COCs are "mixed uniformly" is problematic, There is a strong possibility that there are "hot- } \\
\text { spots" of higher concentrations, which would mean higher exposure risks. Also the soil } \\
\text { pathway analyses does not address the possibility that radionuclides may exceed the } \\
\text { Regulatory Commission (NRC) definition of Transuranic waste (greater } 100 \mathrm{nCi} / \mathrm{g} \text { ), which } \\
\text { would require transport to WIPP. The risk analysis depends too much on modeling rather than } \\
\text { comprehensive sampling and analysis. }\end{array}$ & \\
\hline 15 & $\begin{array}{l}\text { Shoshone Bannock } \\
\text { Tribes } \\
\text { Roger Turner }\end{array}$ & $\begin{array}{l}\text { Section 2.4.3 Conclusions from Soil Pathways and Groundwater Risk Assessments } \\
\text { The conclusions drawn by DOE, that provides for DOE to leave Curies of Radionuclides in } \\
\text { place and estimates that it would not impact groundwater or human health is based on } \\
\text { assumptions and modeling that underestimate the risks. }\end{array}$ & $\# 15, \# 23$ \\
\hline & & $\begin{array}{l}\text { The Tribes support the clean-up, both for Radionuclides and RCRA wastes from the entire site } \\
\text { and sub-surface of the ETR. . The Tribes do not believe that it is right to leave radioactive } \\
\text { contamination in any sumps, piping, sub-structures or sub-surface soils at these sites. The } \\
\text { Shoshone-Bannock Tribes have consistently, over the years, advocated that the DOE at INL, } \\
\text { once it's missions are complete, restore the lands and return them to the Department of Interior, } \\
\text { whereupon the Tribes may have unrestricted access to them. This Treaty right cannot ever be } \\
\text { provided to the Tribe if DOE decommissions these sites with remaining contamination, and } \\
\text { with restrictions or fences that deny access to the Tribes. To that extent, the Tribes request } \\
\text { complete restoration of the ETR, back to their original state. DOE has had twenty years since } \\
\text { these facilities have been deactivated - plenty of time to have carried out a completed RCRA } \\
\text { and CERCLA clean-up. }\end{array}$ & \\
\hline 16 & $\begin{array}{l}\text { Shoshone Bannock } \\
\text { Tribes } \\
\text { Roger Turner }\end{array}$ & $\begin{array}{l}\text { Alternative Analysis } \\
\text { The Tribes agree with the assessment that the no-action alternative unnecessarily risks human } \\
\text { health from, among other things, Niobium- } 94 \text { and Niobium } 95 \text { (Nb-94 and Nb-95), which has a } \\
\text { half-life of over } 20,000 \text { years. Consequently, the Tribes support the removal of the ETR vessel. } \\
\text { As to the question of whether the ETR should be disposed at the ICDF, that is a more difficult } \\
\text { decision. The Tribes are concerned that there may be "hot-spots" of radionuclides that exceed } \\
\text { the Waste Acceptance Criteria (WAC) for the ICDF. Such a possibility was not adequately } \\
\text { addressed in the draft NTCRA. }\end{array}$ & $\# 1, \# 21$ \\
\hline
\end{tabular}




\begin{tabular}{|c|c|c|c|}
\hline$\#$ & Submitted by & Comment & $\begin{array}{l}\text { Appendix A } \\
\text { Response } \\
\text { References }\end{array}$ \\
\hline & & $\begin{array}{l}\text { The DOE's assessment: "Alternative } 4 \text { presents increased public hazards, both real and } \\
\text { perceived during transportation of the vessel over public highways and through congested } \\
\text { metropolitan areas between INL and an off-site disposal facility." This assessment seems to } \\
\text { present a switch in policy that supports the use of the INL for a permanent repository for } \\
\text { nuclear waste. It appears to be a contradiction to the spirit, if not the letter, of the BATT } \\
\text { Agreement and the WIPP transportation agreements. For the State of Idaho and DOE to make } \\
\text { this argument presents a policy shift to support the INL as a repository. The Tribes do not want } \\
\text { unnecessary shipments through the Reservation, but by the same token, they do not want } \\
\text { nuclear waste left in p lace untreated at the INL. }\end{array}$ & \\
\hline 17 & $\begin{array}{l}\text { Shoshone Bannock } \\
\text { Tribes } \\
\text { Roger Turner }\end{array}$ & $\begin{array}{l}\text { The DOE should have added another alternative: To carry out a supplemental RI/FS and } \\
\text { ROD under the existing Operable Units. DOE has mistakenly opted for a Removal without } \\
\text { providing the option to the Tribes or other stakeholders to comment on the pros and cons of } \\
\text { DOE carrying out a supplemental RI/FS and ROD to complete the proposed work. }\end{array}$ & $\# 12$ \\
\hline 19 & $\begin{array}{l}\text { Shoshone Bannock } \\
\text { Tribes } \\
\text { Roger Turner }\end{array}$ & $\begin{array}{l}\text { 5.1.1.2 Protectiveness: Worker Risk } \\
\text { In this section DOE outlines the reasons for leaving nuclear waste in place because of the } \\
\text { increased risk posed to workers by removing the ETR. This seems to be contradictory to other } \\
\text { clean-up priorities at the INL. DOE's position does not appear to be consistent with Pit } 4 \text { and } \\
\text { Pit } 9 \text { waste clean up plans which have been approved, and which provide for treatment of the } \\
\text { radionuclide -containing wastes, some of which contains higher concentrations than expected } \\
\text { at ETR. } \\
\text { At Pit } 4 \text {, at the INL is undergoing a clean-up plan to remove hot-spots of Rock Flats waste that } \\
\text { contains Uranium isotopes, VOCs and transuranic (TRU) radionuclides. The plan includes the } \\
\text { construction of temporary, relocatable structure that houses excavation, excavated NTW } \\
\text { staging, and personnel and equipment ingress and egress activities. The retrieval enclosure } \\
\text { (RE) provides weather protection to allow for vear-round operations and protection of the }\end{array}$ & $\# 5$ \\
\hline
\end{tabular}




\begin{tabular}{|c|c|c|c|}
\hline \# & Submitted by & Comment & $\begin{array}{l}\text { Appendix A } \\
\text { Response } \\
\text { References }\end{array}$ \\
\hline & & $\begin{array}{l}\text { workers. Pit } 9 \text { clean-up was designed by DOE to be a demonstration project that would provide } \\
\text { a method of retrieving subsurface, radionuclide contaminated soils, while being protective of } \\
\text { workers. In the Pit } 9 \text { process workers place each backhoe bucket of contaminated soil and } \\
\text { debris into a glovebox, and scan it to determine radioactivity levels. Using the enclosed } \\
\text { glovebox system, workers will then sort, sample and repackage the waste material into new } \\
\text { barrels. Workers do not come into direct contact with the waste during the retrieval process, } \\
\text { and are protected through engineered barriers. } \\
\text { In FY04 a portion of Pit } 9 \text { was excavated. Based on information gained from Pit } 9 \text {, a removal } \\
\text { action is in process on one-half acre of Pit } 4 \text {, which contains some of the highest concentrations } \\
\text { of transuranic and organic waste in the SDA. }\end{array}$ & \\
\hline 20 & $\begin{array}{l}\text { Shoshone Bannock } \\
\text { Tribes } \\
\text { Roger Turner }\end{array}$ & $\begin{array}{l}\text { Summary } \\
\text { The DOE should carefully consider re-issuing the NTCRA-EE/CA for comments with a more } \\
\text { complete explanation of where the Deactivation activities leave off and the removal activities } \\
\text { begin. As it now stands the reader of the EE/CA has no idea about the transition, and how to } \\
\text { ensure that there is not a gap in remediation or removal. Prior to presenting the NTCRA, the } \\
\text { DOE should have presented to the Tribes other alternatives, including one that would revise } \\
\text { existing RI/FS and ROD before jumping ahead with a NTCRA. DOE should have reviewed for } \\
\text { the Tribes the alternative under } 40 \text { CFR part } 300.415(\mathrm{~g}) \text { which is to do a removal followed by } \\
\text { remedial response. DOE had an obligation to the Tribes to discuss alternatives before they } \\
\text { make unilateral decisions on clean-up, especially those that make a difference in the amount of } \\
\text { wastes left buried at the INL. The Tribes should also have been consulted on DOE's } \\
\text { development of the Remedial Action Objectives (RAOs) at the ETR. }\end{array}$ & $\# 11, \# 22$ \\
\hline 21 & $\begin{array}{l}\text { Shoshone Bannock } \\
\text { Tribes } \\
\text { Roger Turner }\end{array}$ & $\begin{array}{l}\text { The risk assessments that lead to the alternative selections appear to be based on modeling and } \\
\text { estimates that are not adequately substantiated with actual testing. The Tribes are very } \\
\text { concerned about risks posed by leaving radionuclide-contaminated soils in place when there } \\
\text { are technologies available to retrieve, treat and dispose of ETR wastes off-site. DOE's proposal } \\
\text { to leave radionuclides in the soil and vessel such as Nb-94 and Nb-95 with half-lives of over } \\
20,000 \text { years is very troublesome to the Tribes and we have a concern that some "hot-spots" in } \\
\text { the subsurface and vessel area may exceed the Waste Acceptance Criteria (WAC) level for the } \\
\text { disposal at the ICDF, or become mobilized and reach the Snake River Plain Aquifer. DOE has }\end{array}$ & $\begin{array}{l}\# 1, \# 5, \# 15, \\
\# 18\end{array}$ \\
\hline
\end{tabular}




\begin{tabular}{|c|c|c|c|}
\hline \# & Submitted by & Comment & $\begin{array}{l}\text { Appendix A } \\
\text { Response } \\
\text { References }\end{array}$ \\
\hline & & $\begin{array}{l}\text { carried out extensive demonstration projects such as that at Pit } 4 \text { and Pit } 9 \text { that were designed } \\
\text { to allow DOE to safely retrieve and treat and ship wastes. }\end{array}$ & \\
\hline 22 & $\begin{array}{l}\text { Shoshone Bannock } \\
\text { Tribes } \\
\text { Roger Turner }\end{array}$ & $\begin{array}{l}\text { No project could be more applicable for DOE to demonstrate their capability than to use this } \\
\text { technology to clean-up and restore the soils and vessel at the ETR. If DOE continues to claim } \\
\text { that risks to workers automatically drives the preferred alternative, in such a way that wastes } \\
\text { are always left in place - the INL will surely be the Nation's new primary nuclear waste } \\
\text { repository. If DOE should deny the Tribes' above-referenced request to re-draft the EE/CA, } \\
\text { and revise the alternative options; the Tribes urge DOE to select Alternative } 4 \text { which provides } \\
\text { for the optimum clean-up of these lands. }\end{array}$ & $\# 7, \# 8, \# 22$ \\
\hline 23 & Coalition 21 & $\begin{array}{l}\text { The EE/CA emphasizes alternatives } 2 \text { and } 3 \text {, and we comment only on these two alternatives. } \\
\text { These alternatives differ only in that \#3 provides for removal of the vessel from the RTC } \\
\text { (formerly TRA), while \#2 leaves the reactor in place. Although not stated in the EE/CA, we } \\
\text { assume that for \#2 a thick concrete cap with a steep sloping top (perhaps conical) would be } \\
\text { placed on top of the reactor as a radiation shield, and to deflect precipitation from contacting } \\
\text { the reactor. For both alternatives all material above ground level is to be removed, and the } \\
\text { EE/CA says that much of the below ground material is now being removed, though some } \\
\text { material contaminated with low level radioactivity or hazardous material would be left in place } \\
\text { below grade with either alternative. }\end{array}$ & $\# 2, \# 20$ \\
\hline 24 & Coalition 21 & $\begin{array}{l}\text { The EE/CA found the risk from ingestion of ground water to be less than } 1 / 10 \text { of the maximum } \\
\text { acceptable for either alternative. There is no discussion of the major reasons for this, but one } \\
\text { would assume that any reasons would also apply to the ingestion of soil, which was found to } \\
\text { become an unacceptable risk. However the EE/CA does not mention why two different sets of } \\
\text { radionuclides were important for groundwater risk vs soil risk. It would seem that water borne } \\
\text { transport is necessary for either of the risks. }\end{array}$ & $\# 9$ \\
\hline 25 & Coalition 21 & $\begin{array}{l}\text { We note that identical costs for alternatives } 2 \text { and } 3 \text { are projected for operation and monitoring, } \\
\text { i.e., after closure. We assume that this is because the risk from groundwater ingestion was } \\
\text { found to be small enough to be acceptable, and because underground monitoring of the RTC is } \\
\text { required by other past activities, with monitoring wells already in place for that purpose. In } \\
\text { other words, neither alternative imposes additional monitoring requirements. }\end{array}$ & $\# 10$ \\
\hline
\end{tabular}




\begin{tabular}{|c|c|c|c|}
\hline \# & Submitted by & Comment & $\begin{array}{l}\text { Appendix A } \\
\text { Response } \\
\text { References }\end{array}$ \\
\hline 26 & Coalition 21 & $\begin{array}{l}\text { The risk from soil ingestion for Alternative } 2 \text { is postulated to be because of a spread of } \\
\text { radioactivity from the disintegrating reactor vessel into the surrounding soil, with only } \\
\text { negligible contribution from material already outside the vessel. For alternative } 2 \text { we expect } \\
\text { disintegration of the concrete cap to be very slow in our dry climate. The subsequent corrosion } \\
\text { of the reactor vessel after the disintegration of the cap would also be slow. We note that the } \\
\text { buried high level waste tanks at the INTEC have shown no measurable corrosion after } 50 \\
\text { years. Finally, the oxide corrosion products of nickel and niobium, the principal elements of } \\
\text { concern, are nearly insoluble, and so would migrate very slowly even with an appreciable flow } \\
\text { of water, which does not exist now, and is not to be expected in the future. Thus it would be } \\
\text { centuries until an appreciable quantity of the radioactivity moved away from the reactor, } \\
\text { contrary to what was arbitrarily assumed in the EE/CA. By this time, the nickel-63 would not } \\
\text { contribute significantly to the risk. However, the most unreasonable assumption in the analysis } \\
\text { is that the corrosion products would migrate horizontally, rather than primarily downward. } \\
\text { There is no mechanism for ground water to move horizontally, except when in contact with an } \\
\text { impermeable rock or clay layer. Almost equally unreasonable is the assumption that the } \\
\text { radioactivity would accumulate at the RTC, rather than continuing to disperse in whatever } \\
\text { direction it was already moving as it moved away from the corroding reactor vessel. }\end{array}$ & \#4 \\
\hline 27 & Coalition 21 & $\begin{array}{l}\text { Finally we can expect settlement in this entire area to be sparse unless there are future } \\
\text { industrial opportunities there, and maybe not even then. In the hay day of the INEL, efforts to } \\
\text { establish a nearby settlement had only meager success. Atomic City now has a population of } 25 \\
\text { people. The likelihood of someone living right at the RTC is remote. }\end{array}$ & \#6 \\
\hline 28 & Coalition 21 & $\begin{array}{l}\text { After making this succession of inflated assumptions of risk, the EE/CA arrives at a risk of } \\
1.54 \times 10-4^{*}, \text { which is just over the accepted limit, of } 1.0 \times 10-4 \text {. Based on this marginal } \\
\text { exceeding of the allowed risk, the expensive operation of removing the reactor is proposed. } \\
\text { There must be better ways of expending resources. We strongly support putting a concrete cap } \\
\text { over the reactor vessel and leaving it in place, according to alternative } 2 \text {. The cap could be the } \\
\text { same as one put on top of a landfill near INTEC which has a planned lifetime of } 1000 \text { years. } \\
\text { We note that similar or greater amounts of radioactivity have been grouted in place in the } \\
\text { calciner at INTEC. *The risk components of Table } 2-5 \text { add to } 1.54 \times 10-4 \text {. What was the } \\
\text { justification for rounding it up to } 2.0 \times 10-4 \text { ? }\end{array}$ & $\# 5, \# 6, \# 10$ \\
\hline
\end{tabular}




\begin{tabular}{|c|c|c|c|}
\hline \# & Submitted by & Comment & $\begin{array}{l}\text { Appendix A } \\
\text { Response } \\
\text { References }\end{array}$ \\
\hline 29 & Glen Briscoe & $\begin{array}{l}\text { Do the minimum to balance risk with cost. Don't spend many dollars to excessively minimize } \\
\text { risk. No action is probably the best and off site disposal is obviously way too costly. The public } \\
\text { comment should be taken seriously only if it reveals any flaws in your preferred option it is not } \\
\text { a democratic process. }\end{array}$ & $\# 16$ \\
\hline 30 & $\begin{array}{l}\text { Citizen's Advisory } \\
\text { Board }\end{array}$ & $\begin{array}{l}\text { DOE did not do a thorough job of listing the reasons for each Alternative in the EE/CA. } \\
\text { - There was very little how this is (or is not) consistent with the overall Idaho Cleanup } \\
\text { Project. } \\
\text { - The "reduce the footprint" concept seems to be one of the most important plus factors } \\
\text { in both Alternative } 3 \text { and } 4 \text {. This argument should be in the EE/CA. } \\
\text { - The difference between Alternative } 2 \text { and } 3 \text { can not be very much when it comes to } \\
\text { residual radioactive contamination once the vessel has been either grouted in place or } \\
\text { moved to the land fill and grouted. } \\
\text { - Since Alternative } 3 \text { has a greater amount of worker exposure and industrial risk, there } \\
\text { should have been more in Alternative } 3 \text { on how you planned to mitigate theses risks. } \\
\text { This information was received during the latter part of CAB meeting. }\end{array}$ & $\# 2, \# 5, \# 7$ \\
\hline 31 & $\begin{array}{l}\text { Citizen's Advisory } \\
\text { Board }\end{array}$ & $\begin{array}{l}\text { Alternative } 2 \text { should have been given more analysis and consideration. } \\
\text { - With the right kind of protective cover, such as a concrete or stone pyramid or other } \\
\text { monumental structure engraved with appropriate warning symbols such as the } \\
\text { universal symbol for radioactivity, it would be protective of human health well beyond } \\
2095 \text { by preventing such land use. } \\
\text { - It was unclear why Alternative } 2 \text { wasn't by far the cheapest why (way) to handle this } \\
\text { program as well. It seems highly unlikely it would cost } \$ 500,000 \text { (this number was } \\
\text { presented in present value, not annual costs) per year to monitor the site. } \\
\text { - There could have been an alternative } 2 \mathrm{~A} \text {. This would have included a permanent cover } \\
\text { over the grouted ETR. }\end{array}$ & $\# 2, \# 6, \# 10$ \\
\hline 32 & Citizen's Advisory & The cost factors in the total cost were not clear. & $\# 10, \# 17$ \\
\hline
\end{tabular}




\begin{tabular}{|c|c|c|c|}
\hline \# & Submitted by & Comment & \begin{tabular}{|l|} 
Appendix A \\
Response \\
References \\
\end{tabular} \\
\hline & Board & $\begin{array}{l}\text { - Since this may or may not be an important part of each alternative, they certainly } \\
\text { should have been covered in a clear and concise manner. } \\
\text { - For Future EE/CA's, develop more complete cost comparison analysis. Use present } \\
\text { value of money method. } \\
\text { - Future operating cost should be included in the alternatives. However, it was clear } \\
\text { from the conference call and the CAB meeting that not enough effort had been put into } \\
\text { this. It was implied that Alternative } 2,3 \text {, and } 4 \text { had the same operating costs. We now } \\
\text { know that this cannot be true. One of the justifications for Alternative } 3 \text { vs. } \\
\text { Alternative } 2 \text { was the verbal assurance that Alternative } 3 \text { would have lower, but } \\
\text { unspecified, ongoing costs vs. Alternative } 2 \text {. also need to see some breakdown of costs } \\
\text { for a typical year such as sampling labor, lab analysis costs, etc. This shows diligence. } \\
\text { When you convert this to present worth, you should indicate how many years are } \\
\text { included and what discount/interest rate you used. It should stop at } 20 \text {, as the } \\
\text { requirements beyond this could be different, and the present worth of year } 21 \text { through } \\
\text { infinity is close to zero anyway. In the presentation to the CAB, it was good to see that } \\
\text { DOE had rounded off the numbers to } 1-2 \text { significant figures, giving a better } \\
\text { representation of their accuracy. }\end{array}$ & \\
\hline 33 & $\begin{array}{l}\text { Citizen's Advisory } \\
\text { Board }\end{array}$ & $\begin{array}{l}\text { Safety: workers now and public in the future } \\
\text { - The safety of the workers handling this project should have been made a more } \\
\text { important part of the study. Grouting the reactor in place seems like the easiest and } \\
\text { safest way to isolate this hot vessel. Any worker exposure that can be avoided should } \\
\text { be avoided. } \\
\text { - The EPA is using unnecessary exposure for workers to reduce the footprint } \\
\text { - The potential house and garden next to the ETR site argument is unrealistic. No one is } \\
\text { going to build a home next to an abandoned reactor. However, the same exposure } \\
\text { argument could be made for an industrial use or a future INL mission which is far } \\
\text { more credible. } \\
\text { - It was expressed there is not consistency on each item in the Idaho Cleanup Project. It } \\
\text { is not understood why it is acceptable to leave some items in place and to move others. }\end{array}$ & $\# 2, \# 5, \# 6, \# 8$ \\
\hline
\end{tabular}




\begin{tabular}{|c|c|c|c|}
\hline \# & Submitted by & Comment & $\begin{array}{l}\text { Appendix A } \\
\text { Response } \\
\text { References }\end{array}$ \\
\hline & & $\begin{array}{l}\text { - It was suggest that the ICDF might become a high-tech Radioactive Management } \\
\text { Complex (RWMC). Is this consistent with the ICP vision? } \\
\text { - If the reactor vessel is to be removed and placed in the ICDF, then ICDF may be } \\
\text { designated as a waste dump site for everything on the INL. By reducing the footprint, } \\
\text { it seems that we will have put in place another high-level waste storage site. If the } \\
\text { ETR vessel was left in the containment and grouted in place there would only be one } \\
\text { area of concern. There was a senerio that mentioned the types of standards the INL } \\
\text { will be in a } 100 \text {-year time period, those areas that will have administrative controls will } \\
\text { never be able } 9 \text { to) meet residential standards. Further more, there is concern that once } \\
\text { that ICDF is utilized for the ETR vessel, then it will set precedence for all waste } \\
\text { (reactor) to be placed there including waste from other Environmental Management } \\
\text { Sites. Finally, there is concern that if the ICDF is used for this type of waste there may } \\
\text { be a remote possibility that other Environmental Management cleanup sites may look } \\
\text { at the INL as a disposal area. } \\
\text { - CAB was assured by the description of the contractor's extensive large load lifting } \\
\text { experience. } \\
\text { - The idea that DOE is just moving waste around the site from one place to another is } \\
\text { not valid. The RWMC and the ICDF are the two places "planned" for storage of } \\
\text { contaminated material. Limiting the long-term storage of as much of the material at } \\
\text { the site that can be put into these tow locations is how the "footprint" mentioned above } \\
\text { is decreased. }\end{array}$ & \\
\hline 34 & Anonymous & $\begin{array}{l}\text { The available information leads one to believe that DOE has not performed adequate risk } \\
\text { assessments nor included all possible alternatives. When looking at the ETR Complex, there } \\
\text { are two separate issues: the facility (building and support infrastructure) and the reactor vessel. } \\
\text { The buildings and support facility can readily be decontaminated and demolished in a safe } \\
\text { manner in a cost effective way by a knowledgeable contractor. The reactor vessel, on the other } \\
\text { hand, presents an interesting challenge for DOE. So, what should be done with the reactor } \\
\text { vessel? Or perhaps a better question is what can be done with the reactor vessel? }\end{array}$ & $\begin{array}{l}\# 1, \# 7, \# 18, \\
\# 19\end{array}$ \\
\hline
\end{tabular}




\begin{tabular}{|c|c|c|c|}
\hline \# & Submitted by & Comment & $\begin{array}{l}\text { Appendix A } \\
\text { Response } \\
\text { References }\end{array}$ \\
\hline 35 & Anonymous & $\begin{array}{l}\text { Why has DOE ousted Alternative } 1 \text { ? The precedence has already been set at Hanford for long- } \\
\text { term reactor vessel stasis. There is nothing wrong with allowing the radionuclides within the } \\
\text { reactor vessel to decay to a safer level before finalizing a permanent path for disposition } \\
\text { (deferring action). There is no pressing need for the DOE to expose workers and possibly the } \\
\text { public to radiation by moving the reactor vessel. The safest place for the reactor vessel is } \\
\text { within its designed bioshield structure. Although evident that some of the radionuclides within } \\
\text { the reactor vessel are long-lived, allowing decay in a safe effective environment - like the one } \\
\text { where it is currently located - seems a prudent strategy. The buildings and most support } \\
\text { infrastructure can still be demolished to reduce the footprint while maintaining the reactor } \\
\text { vessel's bioshield integrity. From an overall perspective on managing the Reactor Test } \\
\text { Complex, there does not seem to be any obvious issues for maintaining a secure, limited } \\
\text { surveillance stance for an ETR vessel housing as the Advanced Test Reactor, while still } \\
\text { operating, requires the same vigilance. }\end{array}$ & $\# 2$ \\
\hline 36 & Anonymous & $\begin{array}{l}\text { Alternative } 2 \text { also has been ousted by DOE. This decision is based on the threshold criteria for } \\
\text { protectiveness of human health based on the streamlined risk assessment. The basic } \\
\text { understanding is that the total (albeit decayed) inventory of radionuclide, principally those of } \\
\text { the reactor vessel, is "evenly distributed" into the "soil." This is supposedly a conservative } \\
\text { approach. Rather it is an incredible scenario. The radiological inventory in the reactor vessel is } \\
\text { contained in a metal matrix of aluminum, beryllium, hafnium, and stainless steel. The } \\
\text { alternative also imposes a grout within the vessel to stabilize the components. Just how gullible } \\
\text { are the public to believe that at some time in the near distant future all this metal and grout } \\
\text { suddenly becomes soil on which a hypothetical future agricultural family will dwell and } \\
\text { become exposed? When left intact - with the bioshield - the grouted reactor vessel would retain } \\
\text { integrity for thousands of years. Degradation and corrosion are not rapid processes and by no } \\
\text { means would there be an even distribution of radionuclides as components vary with } \\
\text { radioactive concentrations. The risk assessment is an unrealistic oversimplification to dismiss } \\
\text { the complexity of the potential release mechanisms for the reactor vessel. So instead of making } \\
\text { an honest attempt at understanding the complexity of the inherent risks if the reactor vessel } \\
\text { were to be grouted and be left in place, DOE has selected an easy out by not providing the } \\
\text { public with complete information. Alternative } 2 \text { may in fact be the lowest risk near-term to } \\
\text { worker and the public by not moving the vessel as well as the lowest risk for long-term as the } \\
\text { radiological release, transport, and exposure methods are not currently demonstrated in the risk }\end{array}$ & $\begin{array}{l}\# 1, \# 2, \# 6, \\
\# 19\end{array}$ \\
\hline
\end{tabular}




\begin{tabular}{|c|c|c|c|}
\hline \# & Submitted by & Comment & $\begin{array}{l}\text { Appendix A } \\
\text { Response } \\
\text { References }\end{array}$ \\
\hline & & analysis or modeling. & \\
\hline 37 & Anonymous & $\begin{array}{l}\text { Alternative } 3 \text { and } 4 \text { removes the reactor vessel and demolishes the remainder of the complex to } \\
\text { ground (surface) level. DOE prefers Alternative } 3 \text { - disposal of the reactor vessel at the ICDF - } \\
\text { apparently the cheapest alternative that meets the preconceived goals of the DOE. Honestly, } \\
\text { until a better risk assessment is conducted for in-place disposal how can moving the reactor } \\
\text { vessel anywhere (whether a few miles or hundreds of miles) be justified? Without a realistic } \\
\text { assessment, what makes any location, whether it is in-place, the Idaho CERCLA cell, or the } \\
\text { Nevada Test Site, the "right" place to dispose of the reactor vessel? Removal of the reactor } \\
\text { vessel from the bioshield is an obvious radiological risk to workers and will cost millions to the } \\
\text { taxpayer. The characterization of that risk is questionable from the standpoint that there are } \\
\text { serious limitations on obtaining radiological dose readings at the external surface of the reactor } \\
\text { vessel - no access. The modeling done from the limited internal readings is only an attempt at } \\
\text { understanding the potential doses. There are many uncertainties in using the limited number of } \\
\text { readings that have been obtained such as when you place an instrument down the "rabbit" is } \\
\text { the instrument reading the "rabbit" or the environment around the "rabbit"? Seriously, DOE is } \\
\text { willing to place workers at risk based on those limited number of readings, insufficient } \\
\text { characterization, and the resulting uncertainty of models? }\end{array}$ & $\begin{array}{l}\# 2, \# 6, \# 15, \\
\# 19\end{array}$ \\
\hline 38 & Anonymous & $\begin{array}{l}\text { Regardless of the flaws built into the selection of the presented alternatives, one of the issues } \\
\text { DOE has superficially glossed over is that of the beryllium reflector blocks, one of the many } \\
\text { components in the reactor vessel. Critical in determining an acceptable disposal option is the } \\
\text { section of the evaluation report on the vessel's Transuranic inventory. In that section, the } \\
\text { discussion is based on Transuranic formation in the beryllium reflector blocks; however, the } \\
\text { Transuranic concentration is not calculated based on the mass of the beryllium reflector (177 } \\
\mathrm{nCi} / \mathrm{g}) \text {, rather the Transuranic concentration is calculated based on the entire mass of the vessel } \\
\text { (1.99 nCilg). This is a shallow and very poor attempt by the DOE to dilute the Transuranic } \\
\text { concentration. An appropriate analogy would be to say that no Transuranic wastes are buried at } \\
\text { the Subsurface Disposal Area if concentration is based on all the buried wastes (not just those } \\
\text { containers having Transuranics). No one will buy into the fact that there are no Transuranics at } \\
\text { the SDA any more than they will buy into DOE claiming that the ETR beryllium reflectors are } \\
\text { not Transuranic. DOE cannot dismiss this Transuranic waste by claiming the internal } \\
\text { components are "integral" to the vessel as the intelligent design of the reactor integrated the }\end{array}$ & $\# 1, \# 3$ \\
\hline
\end{tabular}




\begin{tabular}{|c|c|c|c|}
\hline \# & Submitted by & Comment & $\begin{array}{l}\text { Appendix A } \\
\text { Response } \\
\text { References }\end{array}$ \\
\hline & & $\begin{array}{l}\text { necessity for replacement of components when the components were past specifications - } \\
\text { especially the beryllium reflectors. Succinctly, the reactor vessel is a package containing a } \\
\text { Transuranic waste, and as such, the package does not meet the waste acceptance criteria at } \\
\text { either the ICDF or NTS. None of the alternatives evaluates removal of any of the components, } \\
\text { so as a waste package containing Transuranics, the only current disposal option open to DOE is } \\
\text { the Waste Isolation Pilot Plant (contingent upon a defense determination). This alternative has } \\
\text { not been discussed. }\end{array}$ & \\
\hline 39 & Anonymous & $\begin{array}{l}\text { The direction taken with respect to the Transuranic waste in the reactor vessel leads one to } \\
\text { question the approach taken on characterization and the averaging methodology of the } \\
\text { radiological constituents. For instance, the radiological inventory of the grid plate - a stainless } \\
\text { steel plate that positions the components in the reactor vessel, has a high quantity of Niobium } \\
94 \text { - high enough to make the component equivalent to NRC's greater-than-class-c waste } \\
\text { requiring deep geological disposal rather than shallow disposal. When averaged over the entire } \\
\text { "waste package" of the reactor vessel volume - this "averages" to be class-c type waste. The } \\
\text { radiological inventory in the grid plate is not homogeneously distributed throughout the } \\
\text { volume of the reactor vessel - and never will be as the metal matrix of the stainless steel will } \\
\text { bind the radionuclides for thousands of years. Certainly no commercial disposal facility would } \\
\text { accept such a legal risk as they must follow the requirements of the NRC's branch technical } \\
\text { position of averaging. Should DOE be allowed to covertly take on this risk without further } \\
\text { characterization and consideration of other viable alternate disposal options? }\end{array}$ & $\# 1, \# 15$ \\
\hline 40 & Anonymous & $\begin{array}{l}\text { Clearly, DOE has, in the evaluation document, made an initial attempt at resolving a very } \\
\text { complex problem; however, the evaluation falls short of any realistic disposition alternative } \\
\text { when considering factors such as the transuranics and the localized radionuclide } \\
\text { concentrations. DOE should consider additional characterization efforts to define the } \\
\text { acceptable disposal path. }\end{array}$ & $\# 1, \# 15$ \\
\hline 41 & $\begin{array}{l}\text { Environmental } \\
\text { Defense Institute } \\
\text { Not transmitted } \\
\text { formally }\end{array}$ & $\begin{array}{l}\text { DOE's Risk Assessment document shows the Engineering Test Reactor (ETR) core slated for } \\
\text { disposal at the ICDF contains } 59,228.1295 \text { curies of radioactive contamination. This is a huge } \\
\text { quantity of extremely deadly radioactive waste to dump over-top the Snake River Aquifer and } \\
\text { within the Big Lost River flood plain. }\end{array}$ & $\# 8$ \\
\hline
\end{tabular}




\begin{tabular}{|c|c|c|c|}
\hline$\#$ & Submitted by & Comment & $\begin{array}{l}\text { Appendix A } \\
\text { Response } \\
\text { References }\end{array}$ \\
\hline 42 & $\begin{array}{l}\text { Environmental } \\
\text { Defense Institute } \\
\text { Not transmitted } \\
\text { formally }\end{array}$ & $\begin{array}{l}\text { DOE Risk Assessment document also states the ETR core at } 22,276 \text { kilograms }(22,276,000 \\
\text { grams). }{ }^{2} \text { However, Engineering Design File uses ETR core mass of } 74,535,000 \text { grams for } \\
\text { calculating the total transuranic content of the core and the beryllium reflector. }{ }^{3} \text { This is a } \\
\text { significant discrepancy because it apparently radically understates the total } \mathrm{nCi} / \mathrm{g} \text { total applied } \\
\text { to the ICDF Waste Acceptance Criteria limit of } 10 \text { nano-curie/gram limit. This discrepancy } \\
\text { must be resolved due to the regulatory implications. }\end{array}$ & $\# 3$ \\
\hline 43 & $\begin{array}{l}\text { Environmental } \\
\text { Defense Institute } \\
\text { Not transmitted } \\
\text { formally }\end{array}$ & 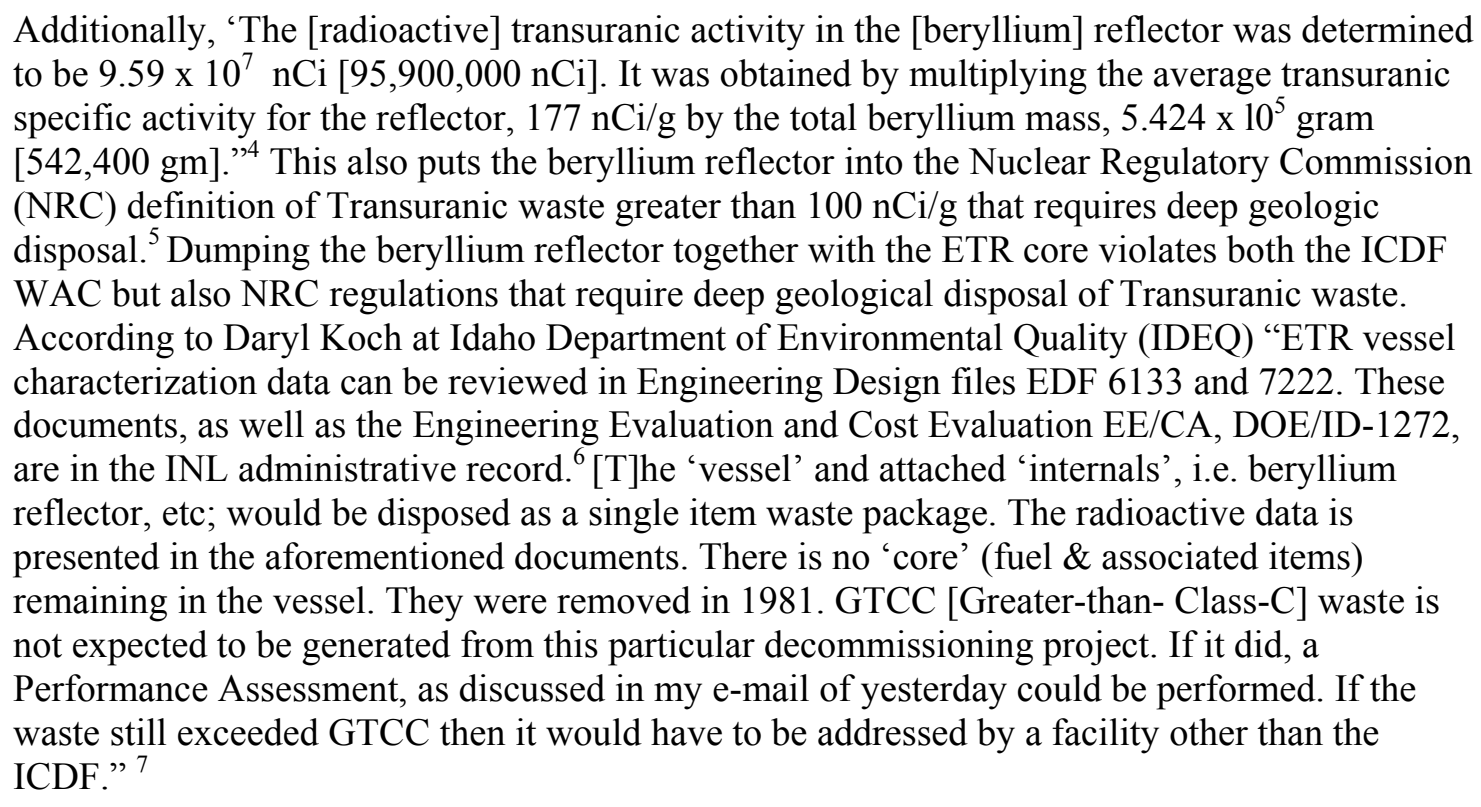 & $\# 1, \# 3$ \\
\hline 44 & $\begin{array}{l}\text { Environmental } \\
\text { Defense Institute } \\
\text { Not transmitted } \\
\text { formally }\end{array}$ & $\begin{array}{l}\text { The issue of Greater-than-Class-C (GTCC) waste is crucial here because of the Nuclear } \\
\text { Regulatory Commission (NRC) definition of; "Waste that is not generally acceptable for near- } \\
\text { surface disposal is waste for which form and disposal methods must be different, and in general } \\
\text { more stringent, than those specified for Class C waste. In the absence of specific requirements } \\
\text { in this part, such waste must be disposed of in a geologic repository as defined in part } 60 \text { or } 63 \\
\text { of this chapter." }\end{array}$ & $\# 1$ \\
\hline
\end{tabular}




\begin{tabular}{|c|c|c|c|}
\hline \# & Submitted by & Comment & $\begin{array}{l}\text { Appendix A } \\
\text { Response } \\
\text { References }\end{array}$ \\
\hline 45 & $\begin{array}{l}\text { Environmental } \\
\text { Defense Institute } \\
\text { Not transmitted } \\
\text { formally }\end{array}$ & $\begin{array}{l}\text { Nuclides identified by NRC regulations for GTCC include C-14, Ni-59, Nb-94, Tc- } 99,1-129 \text {, } \\
\mathrm{Pu}-241, \mathrm{Cm}-242, \mathrm{H}-3 \text {, Co- } 60 \text {, Ni-63, Sr-90, Cs-137. }{ }^{9} \text { All of these radionuclides are in the ETR } \\
\text { vessel and reflector slated for near-surface disposal in significant quantities at the ICDF near- } \\
\text { surface dump site. For instance, see the long-lived radionuclides; Cobalt-60 concentrations of } \\
1,970 \mathrm{Ci} \text {; Ni-63 concentrations of } 24,200 \mathrm{Ci} \text {. }\end{array}$ & $\# 1$ \\
\hline 46 & $\begin{array}{l}\text { Environmental } \\
\text { Defense Institute } \\
\text { Not transmitted } \\
\text { formally }\end{array}$ & $\begin{array}{l}\text { Clearly, DOE's intent to intern the ETR reactor core and components as a single unit in the } \\
\text { ICDF will violate the ICDF Waste Acceptance Criteria (WAC) of } 10 \text { nano-curies per gram } \\
\text { TRU disposal unit by significant amounts. }\end{array}$ & $\# 3$ \\
\hline 47 & $\begin{array}{l}\text { Environmental } \\
\text { Defense Institute } \\
\text { Not transmitted } \\
\text { formally }\end{array}$ & $\begin{array}{l}\text { EDI's preliminary review of the ETR components (including TRU and GTCC waste) slated for } \\
\text { disposal at the ICDF also do not meet the ICDF Waste Acceptance Criteria (WAC). }\end{array}$ & $\# 1$ \\
\hline 48 & $\begin{array}{l}\text { Environmental } \\
\text { Defense Institute } \\
\text { Not transmitted } \\
\text { formally }\end{array}$ & $\begin{array}{l}\text { EDI continues to challenge the long-term adequacy of the ICDF to effectively prevent the } \\
\text { migration of waste contaminates and these concerns are presented again in the below } \\
\text { Attachment that articulates these continuing concerns. }\end{array}$ & $\# 8$ \\
\hline 49 & $\begin{array}{l}\text { The Partnership for } \\
\text { Science \& } \\
\text { Technology }\end{array}$ & $\begin{array}{l}\text { The "Engineering Evaluation/Cost Analysis (EE/CA) for Decommissioning of the Engineering } \\
\text { Test Complex" emphasizes alternatives ( } 2 \text { ) and (3); therefore, the PST Technical Review } \\
\text { Committee focused its efforts on these two alternatives. However, for the record PST does not } \\
\text { consider alternative (1) as acceptable because it does not address the potential threat to human } \\
\text { health. In addition, we do not consider alternative (4) as acceptable because of the excessive } \\
\text { cost and the potential risk to workers. It appears that alternatives (2) and (3) differ only in that } \\
\text { alternative ( } 3 \text { ) provides for the removal of the vessel from the RTC, while alternative (2) leaves } \\
\text { the vessel in place. Although not stated in the EE/CA, we assume that for alternative (2) a } \\
\text { thick concrete cap with a steep sloping top (perhaps conical) would be placed on the top of the }\end{array}$ & $\# 2, \# 20$ \\
\hline
\end{tabular}




\begin{tabular}{|c|c|c|c|}
\hline \# & Submitted by & Comment & $\begin{array}{l}\text { Appendix A } \\
\text { Response } \\
\text { References }\end{array}$ \\
\hline & & $\begin{array}{l}\text { reactor as a radiation shield, and to deflect precipitation from contracting the reactor. For both } \\
\text { options all material above ground level is removed, and the report appears to state that much of } \\
\text { the below ground material is not being removed. Are we correct in this assumption? }\end{array}$ & \\
\hline 50 & $\begin{array}{l}\text { The Partnership for } \\
\text { Science \& } \\
\text { Technology }\end{array}$ & $\begin{array}{l}\text { The EE/CA found the risk from ingestion of ground water to be less than } 1 / 10 \text { of the maximum } \\
\text { acceptable. There is no discussion of the major reasons for this, but one would assume that any } \\
\text { reasons would also apply to the ingestion of soil, which was found to be an unacceptable risk. } \\
\text { However, the EE/CA does not mention why the radionuclides of major concern for soil } \\
\text { ingestion did not even need to be considered for ground water ingestion. }\end{array}$ & $\# 9$ \\
\hline 51 & $\begin{array}{l}\text { The Partnership for } \\
\text { Science \& } \\
\text { Technology }\end{array}$ & $\begin{array}{l}\text { The risk from soil ingestion for alternative (2) is to be because of a distribution of radioactivity } \\
\text { from the disintegrating reactor vessel, with only negligible contribution from material already } \\
\text { outside the vessel. }\end{array}$ & $\# 4$ \\
\hline & & $\begin{array}{l}\text { We anticipate disintegration of the concrete cap to be very slow in the dry climate. The } \\
\text { subsequent corrosion of the reactor vessel after disintegration of the cap would also be slow. } \\
\text { We note that the buried high level waste tanks at the INTEC have shown no measurable } \\
\text { corrosion after } 50 \text { years. Finally, the oxide products of nickel and niobium, the primary } \\
\text { elements of concern, are nearly insoluble, and so would migrate very slowly even with an } \\
\text { appreciable flow of water, which does not exist now, and is not expected in the future. Thus, it } \\
\text { would centuries until an appreciable quantity of the radioactivity moved away from the reactor, } \\
\text { contrary to what was arbitrarily assumed in the EE/CA. By this time, the Ni-63 would not } \\
\text { contribute significantly to the risk. We do not understand the assumption in the analysis that } \\
\text { the corrosion products would migrate horizontally, rather than downward. There are no } \\
\text { mechanisms for water to move horizontally, except when in contact with impermeable rock } \\
\text { layers. We also do not agree with the assumption that the radioactivity would accumulate at } \\
\text { the RTC, rather than continuing to disperse in whatever direction it was already moving as it } \\
\text { moved away from the corroding reactor vessel. }\end{array}$ & \\
\hline 52 & $\begin{array}{l}\text { The Partnership for } \\
\text { Science \& } \\
\text { Technology }\end{array}$ & $\begin{array}{l}\text { We anticipate human activity in this entire area to be rare unless there are future industrial } \\
\text { opportunities there, and maybe not even then. The prospect of someone ever living near the } \\
\text { RTC site is remote at best. }\end{array}$ & $\# 6$ \\
\hline
\end{tabular}




\begin{tabular}{|l|l|l|l|}
\hline$\#$ & Submitted by & Comment & $\begin{array}{l}\text { Appendix A } \\
\text { Response } \\
\text { References }\end{array}$ \\
\hline 53 & $\begin{array}{l}\text { The Partnership for } \\
\text { Science \& } \\
\text { Technology }\end{array}$ & $\begin{array}{l}\text { It also appears to us that due to the past practice use of using injection wells, long term } \\
\text { monitoring will continue to be needed at the RTC site. Is there an estimate for the cost of this } \\
\text { long term monitoring? }\end{array}$ & $\# 10$ \\
\hline 54 & $\begin{array}{l}\text { The Partnership for } \\
\text { Science \& } \\
\text { Technology }\end{array}$ & $\begin{array}{l}\text { In closing, it appears to us that alternative (2) is a technically sound solution based on the } \\
\text { information provided. With this information, we could not identify any significant reason(s) } \\
\text { for expending the financial resources that would be needed for alternative (3). }\end{array}$ & $\# 2, \# 6$ \\
\hline
\end{tabular}




\section{Appendix C}

\section{Citizen's Advisory Board ETR Engineering Evaluation/Cost Analysis Recommendation}




\section{Citizens Advisory Board}

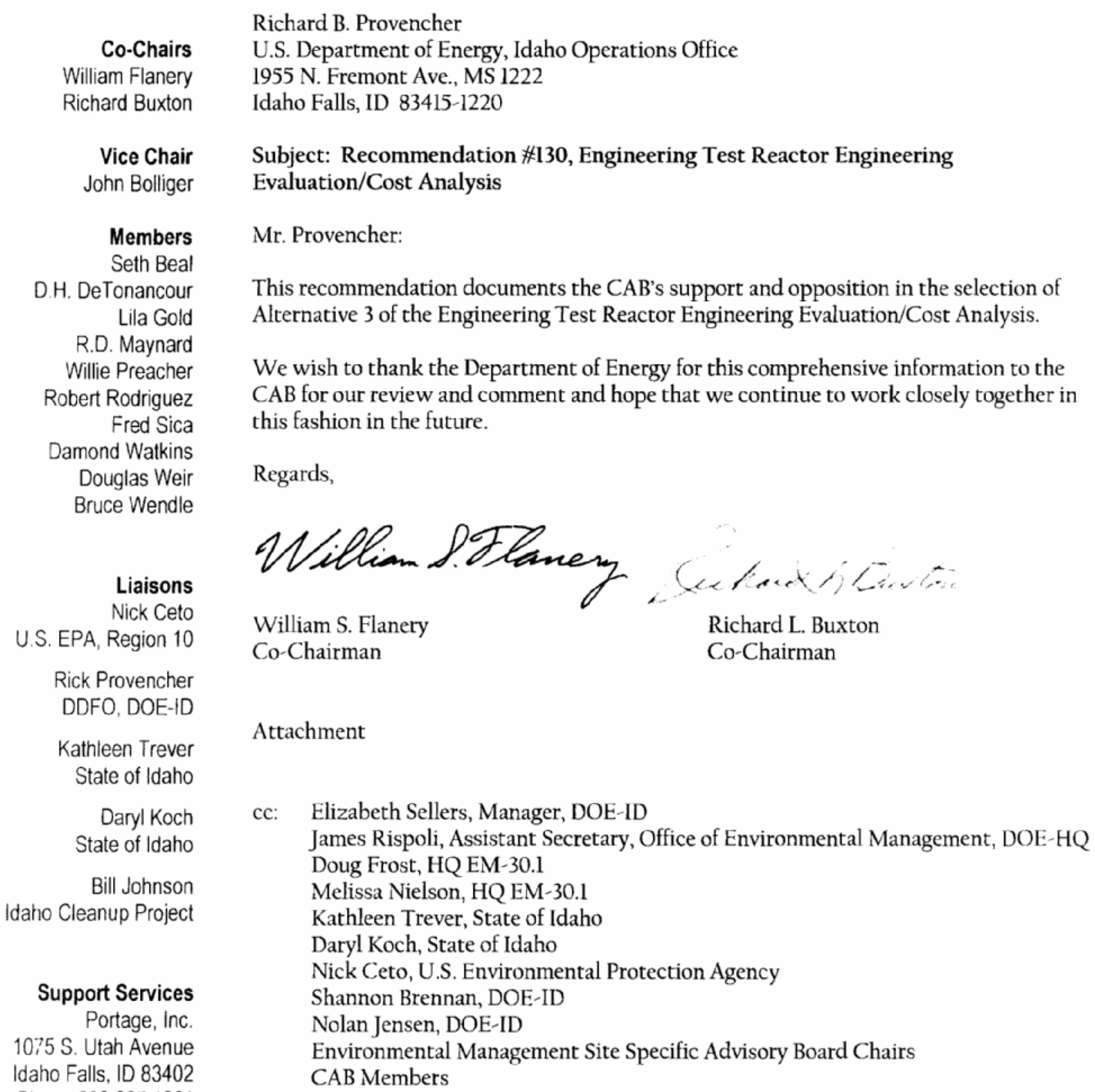

We wish to thank the Department of Energy for this comprehensive information to the $\mathrm{CAB}$ for our review and comment and hope that we continue to work closely together in this fashion in the future.

Regards,

William S. Flanery
Co-Chairman

Richard L. Buxton Co-Chairman

Attachment

cc: Elizabeth Sellers, Manager, DOE-ID

James Rispoli, Assistant Secretary, Office of Environmental Management, DOE-HQ Doug Frost, HQ EM-30.1

Melissa Nielson, HQ EM-30.1

Kathleen Trever, State of Idaho

Daryl Koch, State of Idaho

Nick Ceto, U.S. Environmental Protection Agency

Shannon Brennan, DOE-ID

Nolan Jensen, DOE-ID

Environmental Management Site Specific Advisory Board Chairs

CAB Members 


\title{
Engineering Test Reactor Engineering Evaluation/Cost Analysis
}

\begin{abstract}
Alternative 3 Selection
At the November 2006 meeting, the Citizens Advisory Board (CAB) received a presentation and engaged in lengthy discussion with various Department of Energy (DOE) and Idaho Cleanup Project (ICP) personnel regarding the Engineering Test Reactor (ETR) Engineering Evaluation/Cost Analysis (EE/CA) The $\mathrm{CAB}$ had received a copy of the EE/CA prior to the meeting and had numerous questions. The CAB expressed appreciation for the effort that was put forth by DOE to address their questions and concerns. Following in-depth discussion, the $\mathrm{CAB}$ voted to support Alternative 3 for the key reasons outlined here:
\end{abstract}

- Balances short-term and long-term Comprehensive Environmental Response, Compensation, and Liability Act (CERCLA) objectives for the site.

- The transfer of the reactor vessel to the Idaho CERCLA Disposal Facility (ICDF) reduces the site footprint for contaminated areas which is one of Environmental Protection Agency's (EPA) principle objectives for the Idaho National Laboratory (INL).

- Personnel radiation exposure is managed within contractor guidelines, well below DOE standards, and consideration is given to industrial safety, and employment continuity.

- Lowest total cost when ongoing costs are considered.

Prior to the vote of support, the consensus deliberation process provided a sense for the level of agreement among the members regarding support of Alternative 3. Among the voting quorum of 10, four fully support Alternative 3, three supports with minor reservations, one supports with reservations, and two were opposed.

The $\mathrm{CAB}$ believes it is important for DOE to understand the concerns expressed during this deliberation, both in support and in opposition to Alternative 3. The CAB also believes it is important for DOE to understand $\mathrm{CAB}$ concerns related to the information - or lack thereof - in this specific EE/CA, as well as suggestions for improvement of future EE/CAs; therefore a brief summary of these items is noted below.

- $D O E$ did not do a thorough job of listing the reasons for each alternative in the $E E / C A$

- There was very little how this is (or is not) consistent with the overall Idaho Cleanup Project.

- The "reduce the footprint" concept seems to be one of the most important plus factors in both Alternates 3 and 4 . This argument should be in the EE/CA.

- The difference between Alternative 2 and 3 can not be very much when it comes to residual radioactive contamination once the vessel has been either grouted in place or moved to the land fill and grouted. 
- Since Alternative 3 has a greater amount of worker exposure and industrial risk, there should have been more in Alternative 3 on how you planned to mitigate these risks. This information was received during the latter part of the $\mathrm{CAB}$ meeting.

- Alternative 2 should have been given more analysis and consideration.

- With the right kind of protective cover, such as a concrete or stone pyramid or other monumental structure engraved with appropriate warning symbols such as the universal symbol for radioactivity, it would be protective of human health well beyond 2095 by preventing such land use as residential.

- It was unclear why Alternative 2 wasn't by far the cheapest why to handle this program as well. It seems highly unlikely it would cost $\$ 500,000$ (this number was presented in present value, not annual costs) per year to monitor the site.

- There could have been an Alternative 2A. This would have included a permanent cover over the grouted ETR.

- The cost factors in the total cost analysis were not clear.

- Since this may or may not be an important part of each alternative, they certainly should have been covered in a clear and concise manner.

- For future EE/CA's, develop more complete cost comparison analyses. Use present value of money method.

- Future operating costs should be included in the alternatives. However, it was clear from the conference call and the $\mathrm{CAB}$ meeting that not enough effort had been put into this. It was implied that Alternatives 2, 3, and 4 had the same operating costs. We now know that this cannot be true. One of the justifications for Alternative 3 vs. Alternative 2 was the verbal assurance that Alternative 3 would have lower, but unspecified, ongoing costs vs.

Alternative 2 . Also need to see some breakdown of costs for a typical year such as sampling labor, lab analysis costs, etc. This shows diligence. When you convert this to present worth, you should indicate how many years are included and what discount/interest rate you used. It should stop at 20 , as the requirements beyond this could be different, and the present worth of years 21 though infinity is close to zero anyway. In the presentation to the CAB, it was good to see that DOE had rounded off the numbers to $1-2$ significant figures, giving a better representation of their accuracy.

- Safety: workers now and public in the future

- The safety of the workers handling this project should have been made a more important part of the study. Grouting the reactor in place seems like the easiest and safest way to isolate this hot vessel. Any worker exposure that can be avoided should be avoided.

- The EPA is using unnecessary exposure for workers to reduce the footprint.

- The potential house and garden next to the ETR site argument is unrealistic. No one is going to build a home next to an abandoned reactor. However, the same exposure argument could be made for an industrial use or a future INL mission which is far more credible. 
- It was expressed there is not consistency on each item in the Idaho Cleanup Project. It is not understood why it is acceptable to leave some items in place and to move others.

- It was suggested that the ICDF might become a high-tech Radioactive Waste Management Complex (RWMC). Is this consistent with the ICP vision?

- If the reactor vessel is to be removed and placed in the ICDF, then ICDF may be designated as a waste dump site for everything on the INL By reducing the footprint, it seems that we will have put in place another high-level waste storage site. If the ETR vessel was left in the containment and grouted in place there would only be one area of concern. There was a scenario mentioned that discussed the type of standards the INL will be in a 100-year time period, those areas that will have administrative controls will never be able meet residential standards. Further more, there is concern that once that ICDF is utilized for the ETR vessel, then it will set precedence for all waste (reactor) to be placed there including waste from other Environmental Management Sites. Finally, there is concern that if the ICDF is used for this type of waste there may be a remote possibility that other Environmental Management cleanup sites may look at the INL as a disposal area.

- $\mathrm{CAB}$ was assured by the description of the contractor's extensive large load lifting experience.

- The idea that DOE is just moving waste around the site from one place to another is not valid. The RWMC and the ICDF are the two places "planned" for storage of contaminated material. Limiting the long-term storage of as much of the material at the site that can be put into these two locations is how the "footprint" mentioned above is decreased. 